\title{
Estudios
}

JOSÉ LUIS SÁNCHEZ-GIRÓN RENEDO, SJ *

\section{EL NUEVO DERECHO PENAL DE LA IGLESIA}

Fecha de recepción: 25 de octubre de 2021

Fecha de aceptación: 11 de noviembre de 2021

RESUMEN: El nuevo Libro VI pretende fomentar más la aplicación del derecho penal canónico. Hay cánones que tienen claramente este sentido, otros que se han reelaborado con la misma intención, y la redacción procura ser más clara definiendo mejor los pasos que se han de dar. Aumenta el número de delitos (los de índole sexual tienen un importante precedente en el m. p. Vos estis lux mundi), la regulación de la remisión de la pena es más rigurosa, se reducen notablemente las penas facultativas y aumentan los plazos de prescripción. Con todo ello se endurece la disciplina penal con respecto al CIC de 1983. Por otro lado, el derecho penal se hace más aplicable a los laicos y se subraya la exigencia de reparar los daños que pueda generar el delito.

PALABRAS CLAVE: abuso; censura; delito; pena expiatoria; menor; persona vulnerable; prescripción; reforma; remisión; reparación.

\section{The New Penal Law of the Church}

ABSTRACT: The new Book VI aims to further promote the application of canon criminal law. There are canons that clearly have this meaning, others that have been reworked with the same intention, and the wording tries to be clearer by defining the better the steps that have to be taken. The number of crimes increases (those

Facultad de Derecho Canónico. Universidad Pontificia Comillas:

jlsgiron@comillas.edu; ORCID: https://orcid.org/0000-0002-6798-6324 
of a sexual nature have an important precedent in the m. p. Vos estis lux mundi), the regulation of the penalty's remission is more rigorous, optional penalties are notably reduced, and there is an increase of the statute of limitations. All this hardens the criminal discipline with respect to the 1983 CIC. On the other hand, criminal law becomes more applicable to the laity, and the requirement to repair the damage that the crime may generate is underlined.

KEY WORDS: abuse; censures; expiatory penalties; minor; offense; prescription; reform; remission; reparation; vulnerable person.

Con la Constitución apostólica de 1 de junio de 2021 Pascite gregem Dei, el papa Francisco promulgaba un nuevo texto del Libro VI (LVI) del Código de Derecho Canónico de 1983 (CIC83), dedicado al derecho penal de la Iglesia, disponiendo que su entrada en vigor — que abrogará el texto del LVI del CIC83- tenga lugar el 8 de diciembre de ese mismo año ${ }^{1}$. Como se puede ver en el propio documento papal, el nuevo LVI es fruto de un largo trabajo que «Benedicto XVI, en 2007, encomendó al Pontificio Consejo para los Textos Legislativos» (PCTL) ${ }^{2}$.

La Constitución apostólica va señalando distintos objetivos que se buscaban. Entre ellos destaca la voluntad de motivar más a las autoridades de la Iglesia a la aplicación del derecho canónico penal, desde la constatación de que se ha recurrido poco a él, ocasionando con ello graves daños y complicando sobremanera numerosos problemas que se iban presentando, por considerar que disuena con el ejercicio de la caridad ${ }^{3}$; un planteamiento que el papa contradice con decisión. Se señala también la voluntad de tener un texto más claro en su redacción y mejorado desde el punto de vista técnico, la de incorporar nuevos «tipos penales»,

1 Para el texto de la Constitución Apostólica, cf. Francisco, Papa. "Constitución apostólica del Santo Padre Francisco Pascite grenem Dei con la que se reforma el Libro VI del Código de Derecho Canónico". Santa Sede. Consultado el 18 de octubre de 2021. https://press.vatican.va/content/salastampa/es/bollettino/pubblico/2021/06/01/ comun0.html

2 Para el texto en español del nuevo LVI, cf. Nuevo Libro VI del Código de Derecho Canónico, 01.06.2021. Santa Sede. Consultado el 18 de octubre de 2021, https://press. vatican.va/content/salastampa/es/bollettino/pubblico/2021/06/01/Liber.html

3 En ese sentido, cf. Gregorio Delgado del Río. La investigación previa. La respuesta de la Iglesia al delito de abuso sexual. Navarra: Editorial Aranzadi, 2014, 23. 
y el propósito de reducir los márgenes de discrecionalidad que el CIC83 deja a la autoridad en la aplicación del derecho sancionador ${ }^{4}$.

Hay una breve mención a prestar mejor atención a las víctimas de los delitos, que a pesar de lo escueto deja traslucir que en el origen de la reforma está el grave y complejo problema de los abusos sexuales a menores por miembros del clero, en el cual se ha subrayado la grave falta de atención a las víctimas por parte de la Iglesia en tiempos pasados y sus lagunas en la protección de víctimas potenciales ${ }^{5}$. Toda esta problemática ha sido profusamente abordada por la Iglesia en los últimos años, generándose diversos textos de valor legal, otros de carácter más exhortativo, y tomándose numerosas iniciativas ${ }^{6}$. Sería desacertado decir que todo el nuevo LVI se explica a partir de este problema y del contexto de medidas que ha ido generando, pero es claro que ha incidido en él.

En esta contribución se abordará el primer objetivo señalado en un apartado específico, y los demás se podrán ir detectando en ese mismo epígrafe y en los que seguirán. Se podrá apreciar también un rasgo del nuevo LVI que no menciona explícitamente la Pascite gregem Dei, pero que se detecta en numerosas novedades: un mayor rigor o endurecimiento de la nueva legislación penal con respecto a la del CIC83.

Siendo una reforma del LVI, el nuevo texto se refiere al derecho penal sustantivo. Con ella no entrará en vigor ninguna novedad que se refiera directamente al derecho procesal en la regulación que tiene dentro del CIC83 (cc. 1717-1739). No obstante, hay novedades en el nuevo LVI que en alguna medida inciden en el terreno procesal. Como quiera que sea, persiste que en el derecho canónico son posibles dos tipos de proceso penal (c. 1342): el judicial, sustanciado ante un juez o tribunal; y el administrativo, que lleva a cabo un Ordinario o un delegado suyo designado para ello.

4 El tipo penal es la acción o conducta para la que se establece una pena, cf. Ángel Marzoa. "De poenis in singula delicta. Introducción”. En Comentario exegético al Código de Derecho Canónico, dirigida y coordinada por Ángel Marzoa, Jorge Miras

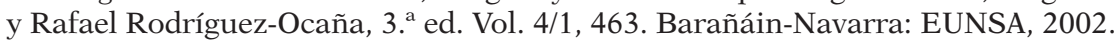

5 Cf. Valeska Ferrer Usó. " Misericordia quiero y no sacrificios» (Os 6,6). Posibles vías de reconciliación en el supuesto del abuso sexual a menores”. Estudios Eclesiásticos 95, n. ${ }^{\circ} 375$ (2020): 922-925.

6 No es posible abundar ahora en esta ingente labor. Baste con remitir al elenco de textos relacionados con ella que ofrece la web oficial de la Santa Sede, cf. "Abusos contra menores. La respuesta de la Iglesia”. Santa Sede. Consultado el 18 de octubre de 2021, https://www.vatican.va/resources/index_sp.htm 


\section{PARA UNA MAYOR APLICACIÓN DEL DERECHO PENAL}

En la línea de motivar más a las autoridades eclesiásticas a la aplicación del derecho canónico penal, cabe destacar el nuevo c. 1311 §2, que no está en el CIC83. Se dirige a las autoridades eclesiásticas transmitiéndoles que es propio de la Iglesia que su deber de proteger y promover el bien de la comunidad y de los fieles lo aborden desde la caridad, el ejemplo de vida, el consejo y la exhortación; pero señala de inmediato que han de hacer uso de la pena canónica si fuera necesario. El efecto de esta disposición de cara a una renovada motivación para la aplicación del derecho penal queda realzado por el hecho de que el CIC83 no contiene un texto así, y por aparecer en el primer canon del LVI.

Otras novedades que pueden situarse en la línea del objetivo señalado se dan mediante la reelaboración del texto de cánones que ya están en el CIC83, con algunos cambios en la redacción y una reordenación de los elementos que renueva el acento que se pone en ellos y genera una nueva orientación del conjunto. Se puede ver en los cc. 1319, 1341, 1343 y 1349.

El c. 1319 se refiere al precepto penal, por medio del cual la autoridad ejecutiva puede establecer una pena para el caso de que una determinada persona incumpla un mandato que se le da en el propio precepto ${ }^{7}$. En el c. 1319 §2 el CIC83 se muestra cauteloso con la aplicación de este instrumento, indicando que "solo debe darse... tras diligente reflexión», mientras que el nuevo LVI indica de manera más directa que se haga uso del mismo si a resultas de esa ponderación, se ve que ha de imponerse un precepto penal ${ }^{8}$.

En cuanto al c. 1341, el CIC83 se expresa nuevamente de manera cautelosa con respecto a la aplicación de derecho penal, indicando al ordinario que «cuide de no promover» las actuaciones penales hasta haber visto que otras alternativas ( «la corrección fraterna, la reprensión u otros medios de la solicitud pastoral») no logran alcanzar los fines que se buscan con

\footnotetext{
7 Cf. Angelo Giuseppe Urru. Punire per salvare. Il sistema penale nella Chiesa. Roma: Edizioni Vivere in, 2001, 48-49.

8 La cautela ante el precepto penal puede justificarse teniendo en cuenta que en alguna medida quebranta el principio de legalidad, según el cual las penas deberían establecerse por la potestad legislativa, no la ejecutiva, cf. Jorge Miras. "Precepto penal". En Diccionario General de Derecho Canónico, coordinada y dirigida por Javier Otaduy, Antonio Viana y Joaquín Sedano, vol. 6, 360. Cizur Menor - Navarra: Universidad de Navarra-Thomson Reuters Aranzadi, 2012.
} 
las penas. En cambio, en el nuevo LVI el canon indica primero y directamente al ordinario que «debe promover» las actuaciones penales cuando haya visto que esas alternativas no funcionan ${ }^{9}$.

En el c. 1343 el CIC83 contempla para los casos en que se permite imponer la pena establecida y también no imponerla (es lo que se llama "pena facultativa») que como alternativa a la segunda opción se pueda imponer una pena menos grave o una penitencia. Por su parte, el nuevo LVI hace que el canon comience con una llamada de atención a enfocar la situación poniendo por delante los fines de la pena. Se transmite la sensación de que el CIC83 favorecía de algún modo la opción de no imponer la pena, y que ahora se pone el acento en la alternativa contraria ${ }^{10}$.

Finalmente, cabe destacar el caso del c. 1349, referido a los supuestos en que se deja a la autoridad que sustancia el proceso la decisión de imponer la pena que considere más adecuada. En el CIC83, la redacción del canon se centra directamente en las limitaciones que se establecen en estos casos para la imposición de penas graves, mientras que el texto del nuevo LVI se refiere en primer lugar a que ha de imponerse una pena (proporcional a la gravedad de los efectos del delito), y sólo después hace referencia a las limitaciones. Una vez más se aprecia un nuevo enfoque de la redacción que subraya mejor la imposición de penas como medida canónica. Es obvio que en el CIC83 queda implícito en la redacción que una pena se ha de imponer; pero ahora se hace explícito y con ello se aporta un texto más donde se subraya el sentido proactivo que quiere darse al derecho penal, priorizando este enfoque por encima del tono cauteloso y un tanto "apocado" (si se puede decir así) que a veces tiene el CIC83 a este respecto ${ }^{11}$.

9 Hay quien ha visto en el c. 1341 del CIC83 un riesgo de mover a una cierta apatía o resistencia a llegar a aplicar el derecho penal, cf. Velasio de Paolis y Davide Cito. Le sanzioni nella Chiesa. 2. ${ }^{a}$ ed. Roma: Urbaniana University Press, 2001, 212.

10 El nuevo enfoque responde a la intención, que se venía abrigando en los trabajos para la reforma, de rebajar los márgenes de discrecionalidad que deja el CIC83 a las autoridades, cf. José Ignacio Arrieta. "El proyecto de revisión de Libro VI de Código de Derecho Canónico”. Anuario de Derecho Canónico 2 (2013): 228.

11 El c. 1349 ha sido a veces criticado por generar un contexto excesivamente benevolente, que perjudica la consecución de los fines eclesiales que se buscan con el derecho canónico penal, cf. Alphonse Borras. Les sanctions dasn l'Église. Paris: Éditions Tardy, 1990, 115. 


\section{NOVEDADES EN EL CAMPO DE LAS PENAS CANÓNICAS}

El nuevo LVI mantiene las categorías de penas que hay en el CIC: latae sententiae (ls) y ferendae sententiae (fs), expiatorias y medicinales o censuras, que siguen siendo tres: excomunión, entredicho y suspensión; penas determinadas e indeterminadas, y penas obligatorias y facultativas. No obstante, se han producido cambios relevantes entre los cuales hay algunos que vale la pena destacar. También hay alguna importante novedad en el campo de los llamados «remedios penales».

En cuanto a las penas ls, la nueva redacción del c. 1324 §3 endurece el efecto previsto en el CIC83 para la presencia de una atenuante en la comisión de un delito que tenga establecida una pena de este tipo: se mantiene que la persona no queda sujeta a la pena ls, pero se permite imponer penas menos graves o penitencias ${ }^{12}$. La doctrina venía señalando que, aun con ese rasgo de benignidad penal tan propio del CIC83, había que entender que era posible el añadido de la nueva redacción ${ }^{13}$; pero sin duda es su incorporación explícita lo que genera una verdadera certeza jurídica.

Por lo que se refiere a las censuras, se introduce un tratamiento más riguroso en lo previsto para la remisión de la pena (el perdón de la pena, se podría decir). Se mantiene que debe remitirse cuando hay cese de la contumacia (cc. 1358 §1 y 1347 §2), cosa que no es obligatorio hacer en las penas expiatorias (esta es una diferencia esencial entre ambos tipos de pena), pero ahora se requiere que esto incluya lo previsto en el c.

12 Basta con ver el c. 1324 para entender que las atenuantes son circunstancias que pueden darse en la comisión del delito, por las cuales se considera justo rebajar la penalización prevista para su comisión.

13 Cf. Ángel Marzoa. "Comentario al c. 1324". En Comentario exegético... Vol. $4 / 1,318$. La imposición de penas se daría en el seno del proceso penal que declare la pena ls. Esto se refiere a que las penas ls se imponen ipso facto en el momento de la comisión del delito (c. 1314), lo cual es una peculiaridad del derecho canónico inédita en los ordenamientos seculares. Se dice que un proceso penal que se sustancie sobre el delito llevará en su caso a la declaración de la pena; no a su imposición, precisamente porque se considera impuesta desde la comisión del delito. La declaración comportará nuevos efectos con respecto a los previstos cuando la pena no está declarada (cc. 1331 §2, 1332 §3, 1333 §), y elimina algunos que sólo se contemplan para la no declarada (p. ej., cc. 1335 §2, 1352, 1357). Sobre estas cuestiones, cf. José Luis Sánchez-Girón. “Análisis de la situación canónica que comportan las penas latae sententiae no declaradas”. Estudios Eclesiásticos 95, n. 375 (2020): 882-883. 
1361 §4: una efectiva reparación de los daños, que sea adecuada «según la prudente discreción del Ordinario» ${ }^{14}$. En el CIC 83 se admite que el cese de la contumacia también se da cuando hay una seria promesa de reparar los daños (c. 1347 §2), y se diría que ahora se va a exigir algún nivel de reparación efectiva ${ }^{15}$. Esta novedad puede relacionarse con la mayor atención prestada en el nuevo LVI a esta cuestión, con diversos delitos para los cuales, junto a la pena, se indica que queda firme la obligación

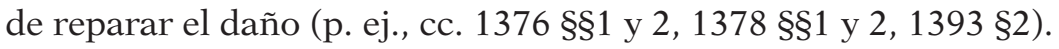

También es relevante la novedad que supone el nuevo c. 1335 §1, al disponer con carácter general que cuando se impone o declara una censura se pueden imponer además penas expiatorias ${ }^{16}$. Esto sale al paso de la posible impresión que razonablemente se podía tener sobre una excesiva benignidad en el tratamiento de las censuras al no poderse negar su remisión, como se acaba de señalar, cuando haya cese de la contumacia ${ }^{17}$. Ahora, la posible imposición de penas expiatorias da pie a que, aun en ese caso, persista la sujeción a penas de este tipo (como se ha indicado, para ellas no hay esa obligación de remitirlas). Por tanto, es un endurecimiento más que se da en el tratamiento de las censuras, aparte del ya señalado en relación a la reparación de los daños de cara a su remisión.

14 Entre las particularidades de las censuras también está (c. 1358 §1) una limitación para la remisión de la pena que no se da en las expiatorias: las censuras no se pueden remitir si no hay cese de la contumacia, la cual se define (c. 1347 §2) como un verdadero arrepentimiento acompañado de una conveniente reparación del escándalo y el daño ocasionado, o de una seria promesa de reparar. En todo caso, la obligación de remitir la pena cuando hay cese de la contumacia hace de las censuras un elemento sui generis del derecho canónico en una perspectiva de derecho comparado, y una expresión muy significativa de valores genuinamente evangélicos: el arrepentimiento y el perdón. Para una reflexión en torno a la alternativa expiatorias-censuras, cf. José Luis Sánchez-Girón. "Penas medicinales y expiatorias". En El Código de Derecho Canónico de 1983. Balance y perspectivas a los 30 años de su promulgación, editado por José Luis Sánchez-Girón y Carmen Peña, 290-295. Madrid: Publicaciones de la Universidad Pontificia Comillas, 2014.

15 No obstante, en el nuevo LVI la redacción del c. 1347 §2 mantiene que se admite la seria promesa de reparación a la hora de estimar que hay cese de la contumacia, lo cual podría generar algún problema de colisión entre ambas disposiciones.

16 El CIC83 contempla expresamente esta posibilidad en casos concretos en los que establece una censura (p. ej., cc. 1364, 1367, 1370 §1), y ahora se hace posible también allí donde no se especifique; p. ej., en cánones como el 1384 y el 1390 §1.

17 Cf. Velasio de Paolis. "Comentario al c. 1349". En Comentario exegético... Vol. 4/1, 419 . 
Otras novedades destacables en las censuras son, por un lado, una mejor presentación de los efectos de la excomunión en el c. 1331 (un desglose más claro y mejor desarrollado), que en último término siguen siendo los mismos, haciendo que sea una pena de extrema gravedad por afectar a fondo en el espacio vital donde se desenvuelve la vida de los fieles (prohíbe recibir y celebrar los sacramentos, ejercer oficios y cargos que se tengan, etc.). Por otro lado, se acepta en el c. 1332 §2 la posibilidad de establecer un entredicho "parcial» (por así decir), de modo que no tenga todos los efectos de la excomunión que en el CIC 83 conforman los del entredicho (los que afectan a los sacramentos y a los actos de culto) sino sólo algunos. Finalmente, se admite que la suspensión sea aplicable a los laicos, al desaparecer del c. 1333 §1 la indicación que tiene en el CIC83 de que sólo puede afectar a los clérigos. Esta extensión de la suspensión a los laicos se viene planteando desde hace tiempo ${ }^{18}$.

En las penas indeterminadas se ha acotado en diversos delitos el margen de indeterminación; es decir, el que se deja a la autoridad que sustancia el proceso penal para decidir cuál o cuáles penas imponer en concreto. Así, donde antes se establecía sin más la imposición de «una pena justa» (máximo margen de discrecionalidad), se pasa en diversas ocasiones a especificar penas concretas (p. ej., en los cc. 1365, 1371 §1 y 1383) con una cierta inclinación a que sean expiatorias de los $\S \S 2-4$ del c. 1336; lo cual elimina la posibilidad contemplada en el CIC, pese a los límites del c. 1349, de imponer una censura ${ }^{19}$. Puede verse, p. ej., en los cc. $1371 \S 2,1372,1376$ §1, 1377 §1 y 1378 §2; y entre los nuevos delitos que

18 Cf., p. ej., Antonio Calabrese. Diritto Penale Canonico. 2. ${ }^{\mathrm{a}}$ ed. Città del Vaticano: Librería Editrice Vaticana, 1996, 123-124. Es algo que cobra sentido considerando que la pena puede afectar al desempeño de oficios y cargos en la Iglesia, y que es creciente el número de laicos que los tienen. Baste pensar en la propia Curia Romana, donde en los últimos años se ha intensificado este fenómeno (en los órganos estables del Sínodo de los Obispos, en los dicasterios, oficina de prensa, etc.). Baste cotejar la siguiente información, cf. José Luis Jiménez. "El Vaticano garantiza la presencia laical en la Curia Romana”. Vida Nueva digital. Consultado el 18 de octubre de 2021. https:/www.vidanuevadigital.com/2018/05/08/el-vaticano-garantiza-la-presencia-laical-en-la-curia-romana/

19 A las limitaciones de este canon del CIC83 ya se ha hecho referencia más arriba. La que afecta en este momento es su indicación de que, en el caso de una pena indeterminada, y a salvo de que la ley disponga otra cosa, la autoridad competente «no debe imponer las penas más graves, sobre todo las censuras, a no ser que lo requiera absolutamente la gravedad del caso». 
se incorporan, en los cc. $1371 \S \S 4$ y 6 y 1376 §1. En otros casos persiste la posibilidad de una censura, pero se añade la de una pena expiatoria (c. 1380); o incluso se asegura la imposición de una pena de este tipo donde antes cabía la posibilidad de que no fuera impuesta (c. 1390 §2 ${ }^{20}$. Todo esto reduce sensiblemente el peso que tienen las penas medicinales en el diseño sancionador del CIC83. Se produce, pues, un claro movimiento hacia una mayor presencia de las penas expiatorias.

En cuanto a las penas facultativas, salvo en el caso del c. 1399 desaparecen allí donde el CIC83 las establece sin más alternativa, como puede verse ahora en los cc. 1371 §2, 1372, 1389, 1390 §2 y 1391; y no hay ningún nuevo delito para el cual se establezca una pena de esa manera. Se entiende que aquí tenemos otro ejemplo de un endurecimiento penal operado por el nuevo LVI. Sí quedan penas facultativas donde ya se establece una pena obligatoria, quedando como una posibilidad que se admite de añadir o no más penas, pero habiendo asegurado que alguna pena habrá (p. ej., c. 1395 §1). También cabe señalar en el ámbito de estas penas, y del endurecimiento penal operado por la reforma, la modificación del c. 1326 §1, referido a las agravantes. En el CIC83 el canon dispone que ante la presencia de este tipo de circunstancias «se puede castigar con mayor gravedad que la establecida», y en el nuevo LVI dice que «se debe» hacer esto ${ }^{21}$.

Por lo que se refiere a las penas expiatorias, el elenco de las mismas que presenta el c. 1336 queda mejor desglosado en el nuevo LVI, distinguiendo con más claridad unas de otras ${ }^{22}$. Aparecen penas nuevas, entre las que destacan las económicas del §2.2 (pagar una multa pecuniaria o suma monetaria para fines de Iglesia) y el §4.5 (privación de la totalidad o de una parte de la remuneración eclesiástica), remitiéndose en ambos

20 Las penas indeterminadas han sido valoradas negativamente por la falta de certeza que generan y su menor eficacia disuasoria, cf. Bruno F. Pighin. Diritto penale canonico. Venezia: Marziamun Press, 2008, 244-245.

21 Como en el caso de las atenuantes, ahora basta con ver el c. 1326 para entender que las agravantes son circunstancias que pueden darse en la comisión del delito, ante las cuales se considera justo agravar la penalización prevista.

${ }^{22}$ Ahora aparecen hasta 16 números, frente a 5 en el CIC83. Sólo con eso, bien puede ser que hasta visualmente el nuevo canon motive más a la hora de tener que escoger una pena cuando se da un margen de decisión. El c. 1336 del CIC83 enuncia diversas penas en un mismo número, con una redacción a veces abigarrada que no transmite bien la sensación de que hay muy diversas posibilidades en el mismo texto. 
casos a normas que las conferencias episcopales habrán de dar al respecto. Cabría pensar que estas penas pueden tener relación con la voluntad que, como ya se ha dicho, manifiesta el nuevo LVI de poner un especial acento en la reparación de los daños que pueda causar la comisión de un delito ${ }^{23}$.

Otras penas que aparecen en el nuevo c. 1336 vienen a ser una especificación de penas que de algún modo se pueden considerar ya contenidas en el CIC83 bajo una formulación más genérica (como privación de un derecho o prohibición de ejercerlo). Sería el caso, p. ej., de las prohibiciones de tener voz activa o pasiva en las elecciones canónicas, de votar en consejos o colegios eclesiales (\$3.6), o de vestir el traje eclesiástico o el hábito religioso (\$3.7), o la privación de la facultad de oír confesiones o de predicar (§4.2). En cambio, desaparece la pena del traslado penal a otro oficio, que está en el c. $1336 \$ 1.4$ del CIC $83^{24}$.

Como no cabía esperar que fuera de otro modo, permanece la pena de expulsión del estado clerical (c. 1336 §5). Se mantiene que nunca aparece explícitamente como la única pena establecida para un determinado delito, sino como una alternativa entre otras con la indicación de que no se excluya su imposición o el añadido de que se imponga en los casos más graves (p. ej., cc. 1364 §2, 1370 §1, 1379 §3, 1382 §1, 1385, 1386 §3, 1392, $1394 \S 1,1395,1397 \S 3,1398 \S 1)$. Otra novedad es la insistencia con que se hace mención específica de la pena de privación del oficio ( 8 veces) en comparación con el CIC83 (2 veces) al establecer la pena en distintos delitos ${ }^{25}$.

23 Remitirse a las conferencias episcopales para regular en lo concreto una determinada materia es muy común en el CIC83, y más en materias económicas (p. ej., cc. 1253,1265 \$2, 1227, 1277, 1292). Cada Conferencia Episcopal podrá acomodar a su territorio el marco en que se puedan mover estas penas (según la situación económica de la zona, la incidencia que pueda tener la legislación estatal, etc.). Quizá, tratar también sobre la posibilidad mencionada de que las cantidades se apliquen a la reparación de los daños.

24 El CIC17 precisaba en el c. 2298.3 que el traslado debía ser «a otro oficio de inferior categoría», inciso del que prescinde el CIC83. Se ha señalado que, aun siendo válido concretar la pena en el traslado a un oficio mejor, esto sería contrario al espíritu de la norma, cf. Calabrese, 133-134. Se podría haber optado por retomar el inciso del CIC17; pero no deja de ser cierto que, sin necesidad de que haya habido la comisión de un delito, ya existe una regulación para el traslado de oficio (cc. 190-191) y una especial para el caso del párroco (cc. 1748-1752).

25 La mención explícita de esta pena asegura más que se permite su imposición, y cobra especial sentido cuando se establece para delitos muy relacionados con el ejercicio de un oficio (p. ej., cc. 1376 §2, 1377 §§1 y 2, 13778 §1 y 1396). 
Aunque no sean penas canónicas propiamente hablando, los remedios penales no dejan de ser instrumentos próximos a las actuaciones penales, y en ellos se produce una importante novedad ${ }^{26}$. Está en el c. 1339 y consiste en la incorporación de dos remedios penales que se unen a la amonestación y la reprensión, ya previstos en el CIC83. Uno de ellos comporta un nuevo impulso para el precepto penal, que se une al ya comentado acerca del c. 1319. Dice el c. 1339 §4 que «el Ordinario dé un precepto penal» a quien ya ha sido amonestado o reprendido varias veces sin que se hayan dado los efectos esperados de abandonar el modo de proceder por el que se dan esas advertencia o reprobación ${ }^{27}$. El otro (§5) se refiere a someter a medidas de vigilancia a quien está en peligro de reincidir en un delito ya cometido, añadiéndolas a la pena que se imponga o declare por ello ${ }^{28}$. En ambos casos cabe apreciar nuevos signos de mayor rigor comparando con el CIC83.

\section{NUEVOS DELITOS}

El nuevo LVI no elimina ningún delito que esté en el CIC83, sino que incorpora una buena cantidad de delitos que no están en él; lo cual es otro claro signo de endurecimiento penal. Por una parte, y con una sola excepción, están los delitos que ya fueron tipificados con posterioridad

${ }^{26}$ Según el c. 1312 \$3 los remedios penales se emplean, sobre todo, para prevenir los delitos.

27 El canon pide que el precepto indique claramente lo que se manda hacer o evitar. Lógicamente, se tratará de algo que no llega a ser un delito, pero que podría llevar a cometer alguno si no se desiste. La creciente presencia del precepto penal se aprecia también en los nn. 64 y 79-81 del vademécum emanado por la Congregación para la Doctrina de la Fe el 16 de julio de 2020 (en adelante «vademécum») para los procesos penales en casos de abuso sexual a menores de edad; cf. Congregación para la Doctrina de la Fe. Vademécum sobre algunas cuestiones procesales ante los casos de abuso sexual a menores cometidos por clérigos, Santa Sede. Consultado el 18 de octubre de 2021, https://www.vatican.va/roman_curia/congregations/cfaith/documents/ rc_con_cfaith_doc_20200716_vademecum-casi-abuso_sp.html

28 Cabe imaginar que estas medidas de vigilancia pueden ser, p. ej., estar en el lugar donde se viva a partir de ciertas horas, o presentarse cada cierto tiempo ante una determinada persona. El canon dice que se imponga por decreto. La diferencia con el precepto sería que no se establece una pena para el caso de incumplir las medidas. Probablemente se esté tomando en consideración que se trata de una persona ya sujeta a penas que se le han impuesto o declarado. 
al CIC83; los cuales han cobrado en todos los casos la condición de delito reservado a la Congregación para la Doctrina de la Fe (CDF), estando recogidos en las normas de 2010 relativas a este tipo de delitos (en adelante «normas de 2010»), y habiendo algunos que ya aparecieron en las normas anteriores sobre esta materia del año 2001 (en adelante, «normas de $2001 »)^{29}$. Se añaden conductas y acciones que aparecen en el m. p. de 7 de mayo de 2019 Vos estis lux mundi (VELM), y que en el momento de su entrada en vigor no estaban tipificados en la Iglesia; y, finalmente, hay delitos que son del todo novedosos en el texto reformado.

\subsection{Delitos ya tipificados con posterioridad al CIC}

Los delitos del primer grupo anteriormente mencionado son los siguientes ${ }^{30}$ :

- Atentar conferir el orden sagrado a una mujer, así como la mujer que atente recibirlo (c. 1379 §3). Fue tipificado en 2007 y pasó a ser delito reservado a la CDF en las normas de 2010 (art. 5.2) ${ }^{31}$.

- Consagración con fin sacrílego de una sola materia o de las dos en la celebración de la Eucaristía o fuera de ella (c. 1382 §2). En realidad, el c. 927 ya prohíbe terminantemente «consagrar una

29 Para el texto de las normas de 2001, cf. p. ej., Federico R. Aznar Gil. Delitos de los clérigos contra el sexto mandamiento. Salamanca: UPSA, 2005, 101-119. Para el texto de las normas de 2010, cf. Normae de delictis Congregationi pro Doctrina Fidei reservatis seu Normae de delictis contra fidem necnon de gravioribus delictis, 21 de Mayo de 2010. AAS 102 (2010): 419-434. Estas normas comportan principalmente diversas particularidades procesales (art. 8-31, en la parte procesal) que llevan a una intervención especial de la CDF para delitos que ellas mismas recogen, considerando que son «más graves» (art. 1-7, en la parte sustancial). Para un trabajo sobre estas normas, cf. p. ej., Velasio de Paolis. "Norme de gravioribus delictis riservati alla Congregazione per la Dottrina de la Fede”. Periodica 91 (2002): 273-312; Kurt Martens. "Les délits les plus graves réservés à la Congrégation pour la Doctrine de la Foi". Revue de Droit Canonique 56 (2006): 201-221.

30 Aparte de los delitos que se van a mencionar, los demás que aparecen en las normas de 2010 están ya recogidos en el CIC83.

31 Para la tipificación del delito, cf. AAS 100 (2008): 403. Tiene como precedente el caso acaecido en 2002 de unas mujeres que recibieron la ordenación sacerdotal en EE. UU. (obviamente, una ordenación nula, que es a lo que se refiere el término «atentar» la ordenación). Para seguir las actuaciones que se llevaron a cabo a propósito del caso, cf. Enchiridion Vaticanum 21 (2002): 481-482.552-553.1100-1103. 
materia sin la otra, o ambas fuera de la celebración eucarística», aun cuando no se haga con finalidad sacrílega (para profanar luego las sagradas especies), pero en el CIC83 no hay establecida una pena para ellas. Las normas de 2001 las tipificaron como delito (art. 2 §2), pero sólo en el caso de que se hagan con ese fin. Las normas de 2010 (art. 3 §2) añaden al tipo penal la consagración de las dos especies en la Eucaristía, siempre en el caso de hacerlo con esa finalidad.

- Grabación o divulgación por los medios de comunicación, con malicia, de una confesión sacramental real o fingida (c. 1386 §3). Fue tipificado ya en $1988^{32}$. Pasó a ser delito reservado a la CDF en $2003^{33}$, y a ser recogido en las normas de 2010 (art. 4 §2) ${ }^{34}$.

- Delito contra el sexto mandamiento del Decálogo (en adelante «abuso sexual») cometido por un clérigo con un menor de edad que tiene entre 16 y 18 años (c. 1398 §1.1). En realidad, el canon se refiere sin más a «un menor», y se entiende que es un menor de 18 años porque así define al menor el c. 97 §1. El c. 1395 §2 del CIC83 refiere este delito de abuso sexual al caso en que el menor tiene menos de 16 años, y no fue hasta las normas de 2001 (art. 4 §1) cuando se aumentó la edad a $18^{35}$. El delito es reservado a la CDF desde ese mismo año, y está recogido también en las normas de 2010 (art. 6 §1.1). Hay abuso sexual por el hecho de que la persona es menor de edad, cualquiera que sea la forma en que se verifique la contravención del sexto mandamiento (haya o no violencia o amenazas, por mencionar modalidades que están en el CIC83 y aparecerán aquí más adelante).

- Abuso sexual cometido por un clérigo con una persona que habitualmente tiene uso imperfecto de razón (c. 1398 §1.1). El tipo

32 Cf. $A A S 80$ (1988): 1367.

33 Cf. "Norme substantiales et processuales promulgate col m.p. Sacramentorum sanctitatis tutela (30 aprile 2001) e successive modifiche”. Ius Ecclesiae 16 (2004): 320.

34 La tipificación de este delito viene motivada por casos reales que habían sucedido, semejantes al que tuvo lugar en 2007, después de ser tipificado, cuando un periodista fingió con varios sacerdotes querer confesarse, planteándoles cuestiones sobre temas polémicos (como el abuso sexual y el aborto), registrando el diálogo que tenían y publicando después con ello un reportaje sensacionalista, cf. Pighin, 437.

35 Ya se había hecho con anterioridad (desde 1994) para la Iglesia de EE. UU., cf. William H. Woestman. Ecclesiastical Sanctions and the Penal Process. 2. ${ }^{\mathrm{a}}$ ed. Ottawa: Saint Paul University, 2003, 270-271. 
penal se refiere a personas mayores de 18 años, pues si no estaríamos en el supuesto anterior, que, p. ej., padecen alguna minusvalía mental (síndrome de Down, ciertas patologías congénitas) o están habitualmente en estado de uso imperfecto de razón como secuela de algún tratamiento farmacológico o del abuso de drogas o alcohol ${ }^{36}$. El delito fue tipificado en las normas de 2010 (art. 6 §1.1), diciendo que este supuesto (en adelante «equiparado») "se equipara» al del menor. Por ello, cabe decir lo mismo que en el caso del menor en cuanto a la forma que adquiera la contravención del sexto mandamiento.

- El clérigo que adquiere, conserva, exhibe o divulga, inmoralmente, en cualquier forma y con cualquier instrumento, imágenes pornográficas de menores (c. 1398 §1.3). El delito (en adelante "pedo-pornografía») fue tipificado en el art. 6 \$1.2 de las normas de 2010 para el caso en que el menor tuviera menos de 14 años, y un rescripto papal de 17 de diciembre de 2019 lo amplió haciendo que el mencionado artículo abarque a todo menor de edad (por tanto, menor de 18 años) $)^{37}$. Sobre lo que haya de entenderse por imágenes pornográficas de menores, cabría tomar como referencia la definición de «material pornográfico infantil» que da VELM en su art. 1.2c: «cualquier representación de un menor, independientemente de los medios utilizados, involucrado en actividades sexuales explícitas, reales o simuladas, y cualquier representación de órganos sexuales de menores con fines predominantemente sexuales ${ }^{38}$.

\footnotetext{
36 Cf. Antonio Rella Ríos. "El abuso sexual en la Iglesia. Conceptualización y tratamiento canónico". Anuario de Derecho Canónico 10 (2021): 29.

37 Cf. Francisco, Papa. "Rescriptum ex audientia SS.MI: Rescripto con el que se aportan algunas modificaciones a las Normae de gravioribus delictis. Santa Sede. Consultado el 18 de octubre de 2021, https://press.vatican.va/content/salastampa/es/ bollettino/pubblico/2019/12/17/rescpi.html. Para el uso de pedo-pornografía cf. p. ej., V. G. Dhas. "Il delitto di pornografia minorile da parte di un chierico". Apollinaris 87 (2014): 167; Federico Lombardi. "El significado de la publicación de las nuevas Normas sobre los delitos más graves”. Santa Sede. Consultado el 18 de octubre de 2021, https://www.vatican.va/resources/resources_lombardi-nota-norme_sp.html.

38 Cf. Francisco, Papa. Carta apostólica en forma motu proprio del Sumo Pontífice Francisco Vos estis lux mundi. Santa Sede. Consultado el 18 de octubre de 2021, https:/www.vatican.va/content/francesco/es/motu_proprio/documents/papa-francesco-motu-proprio-20190507_vos-estis-lux-mundi.html. Para un estudio sobre esta
} 
El nuevo LVI no ha integrado un delito reservado a la CDF que quedó tipificado de manera específica en las normas de 2001 (art. 2 §1.3), siendo recogido también por las de 2010 (art. 3 §1.4). Se trata de concelebrar la Eucaristía con ministros de confesiones cristianas que carezcan de sucesión apostólica y no reconozcan la dignidad del sacramento de la ordenación sacerdotal ${ }^{39}$. El supuesto está comprendido en la prohibición del c. 908 de concelebrar con sacerdotes o ministros de iglesias o comunidades que no estén en plena comunión con la Iglesia católica, con lo cual viene a ser un caso concreto del delito de communicatio in sacris prohibida del c. 1381 (c. 1365 en el CIC 83$)^{40}$. No obstante, se hace extraño que no haya sido integrado como caso específico en el nuevo LVI, pues resulta ser el único delito reservado a la CDF que no quede recogido en el CIC ni con la entrada en vigor del texto reformado (es la excepción a la que se hizo referencia más arriba). Esto no altera que, merced a su tipificación en las normas de 2001, se haya de tener, con la especificidad del tipo penal, por un delito canónico (y reservado a la CDF) que lo es desde ese año ${ }^{41}$.

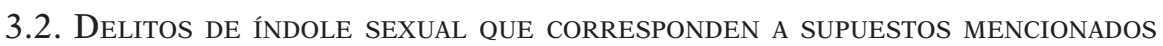 EN VELM}

El LVI recoge nuevos delitos de índole sexual, aparte de los que ya están en el CIC83 o fueron tipificados con posterioridad. Entre los ya tipificados están los delitos del clérigo de abuso sexual a un menor (en el c. 1395 §2 del CIC 83 hasta los 16 años, y en las normas de 2001 entre 16 y 18) o a persona equiparada (desde las normas de 2010) y de pedo-pornografía

compleja materia cf., p. ej., Luis María Uriarte Valiente. Delitos relativos a la pornografía infantil y corrupción de menores. Madrid: Estudios jurídicos, 2006.

39 Esto haría referencia a confesiones del ámbito luterano o protestante, cf. Woestman, 102.

40 Para un tratamiento de este delito, que ha de ponerse en relación inversa con los casos de communicatio in sacris permitida del c. 844, cf. John A. Renken. The Penal Law of the Roman Catholic Church. Ottawa: Saint Paul University Press, 2015, 212-217.

41 La importancia de tener muy claro cuándo se tipifica un delito es obvia, y responde a un elemental principio de cualquier ordenamiento penal: si una acción no está tipificada como delito cuando se lleva a cabo, no es delito ni lo será nunca; tampoco a partir del momento en que se tipifique, si esto se hiciere. A ello se refiere el n. 3 del vademécum. 
(desde las normas de 2010 con imágenes de menores de 14 años, y desde el rescripto de 17 de octubre de 2019 con imágenes de menores entre 14 y 18 años), así como el de abuso sexual con violencia o amenazas y el delito contra el sexto mandamiento cometido públicamente (entiéndase, en lugar público); tres delitos que recoge el c. 1395 \$2 CIC83. Según el razonamiento ya empleado con el equiparado, se entiende que los tres se refieren a un mayor de 18 años no equiparado ni «vulnerable» (trataremos enseguida sobre este término). En el nuevo LVI estos seis delitos están, los tres primeros, en el c. 1398 §1.1 (los dos casos de abuso) y §3 (pedo-pornografía); y los otros tres en el c. 1395 §2 (el delito cometido públicamente) y $\$ 3$ (los supuestos de violencia y amenazas).

Entre los delitos que no están en el CIC83 ni en las normas de 2010, se encuentra, por un lado, el de abuso sexual cometido por un clérigo con una persona «a la que el derecho reconoce igual tutela» que al menor y al equiparado, en el c. 1398 §1.1. En realidad, se trata de la misma persona a la que VELM denomina "persona vulnerable ${ }^{42}$. Sirva, pues, como aproximación a lo que pretenda ser este término lo que dice sobre el mismo el art. $12 \mathrm{~b}$ del m. p.: «cualquier persona en estado de enfermedad, de deficiencia física o psicológica, o de privación de la libertad personal que, de hecho, limite incluso ocasionalmente su capacidad de entender o de querer o, en cualquier caso, de resistir a la ofensa» (según se viene razonando, será una persona mayor de 18 años y no equiparada al menor $)^{43}$. A decir verdad, es la misma definición que se encuentra en el art. 1.3 de la Ley CCXCVII de la Ciudad del Vaticano, del 26 de marzo de 2019, que tipifica como delito para su ámbito de aplicación el abuso sexual a «persona vulnerable» indicando que se considera equiparada al

42 Así lo dijeron Mons. Iannone y Mons. Arrieta, presidente y secretario, respectivamente, del PCTL, en respuesta a una pregunta durante la rueda de prensa que siguió a la presentación por parte de ambos del nuevo LVI el 1 de junio de 2021, emitida por vía telemática en ese momento y accesible después a través de internet, cf. "Conferenza stampa sulle modifiche al Libro VI del Codice di Diritto Canonico". Vatican News. Consultado el 18 de octubre de 2011, https:/www.youtube.com/watch?v=3hNjfpskjOs\&t=370s (minuto 28-32 del vídeo).

43 Sobre los supuestos de abuso de autoridad y persona vulnerable se ha escrito mucho y, seguramente, se seguirá haciendo en busca de definirlos mejor, perfilar los casos concretos que integran, etc. Por aportar alguna referencia concreta a los mismos, cf. Rella Ríos. "El abuso sexual”, 29-30.43-45. 
menor (art. 1.2) ${ }^{44}$. Se ve cómo la legislación del Estado Vaticano ha sido un prototipo y un elemento impulsor en esta materia.

Por otro lado, está el delito del clérigo con imágenes pornográficas de persona equiparada (no recogido de manera explícita por las normas de 2010), que en el c. 1398 §1.3 se integra con el de pedo-pornografía; no así en el caso de que sean imágenes de una persona vulnerable, supuesto que no pasa a ser delito. También está el abuso sexual cometido por un clérigo con abuso de autoridad, en el c. 1395 \$3 (de nuevo, entiéndase que el delito se comete con persona mayor de edad que no es equiparada ni vulnerable $)^{45}$. Se añade en este canon un tipo genérico definido como «el clérigo que $[\ldots]$ obliga a alguien a realizar o sufrir actos sexuales». Se entiende que pretende integrar cualquier forma de abuso sexual cometido por un clérigo y que no responda a un caso específico ya tipificado. A esta clase de tipo penal se la conoce como «tipo residual».

Un cuarto delito que no está ni en las normas de 2010 ni en el CIC83 aparece recogido en el c. $1398 \$ 1.2$ del nuevo LVI. Consiste en que un clérigo implique o induzca a un menor o equiparado o persona vulnerable a exponerse pornográficamente o a participar en exhibiciones pornográficas ${ }^{46}$. Quizá cabría pensar que en el fondo no es un delito más, pues se puede razonablemente interpretar que responde ya al supuesto del c. 1398 §1.1, que comprende, como se ha ido viendo, el abuso sexual en los mismos tres $\operatorname{casos}^{47}$.

44 Cf. Francisco, Papa. Legge n. CCXCVII sulla protezione dei minori e delle persone vulnerabili. Santa Sede. Consultado el 18 de octubre de 2021. https://www.vatican.va/ resources/resources_protezioneminori-legge297_20190326_it.html

45 Para una opinión contraria a que el caso de abuso de autoridad estuviera ya integrado en el c. 1389 §1 del CIC83, cf. José Luis Sánchez-Girón. "El «motu proprio» "Vos estis lux mundi»: contenidos y relación con otras normas del derecho canónico vigente”. Estudios Eclesiásticos 94, n. 371 (2019): 697.

46 En lugar del verbo «implicar», la versión española del LVI que aquí manejamos (ver la nota 1) usa «reclutar»; término que se hace extraño en este contexto, y en lugar del cual se emplea aquí «implicar».

47 Se considera que el tipo penal del abuso sexual comprende una amplia gama de acciones y conductas, desde el lenguaje soez hasta la penetración. Para una visión de esta amplitud, cf. p. ej. John Jay College of Criminal Justice. The Nature and Scope of the Problem of Sexual Abuse of Minors by Catholic Priests and Deacons in the United States: Washington DC: USCCB, 2004, 55. En ese amplio margen no sería difícil encuadrar el c. 1398 §1.2. 
En todos los supuestos vistos hasta aquí, salvo en el delito cometido públicamente, por la vía del autor se produce en el nuevo LVI un notable incremento de delitos. En los casos que ya están en el CIC83 o las normas de 2010, el delito sólo lo es cuando el autor es un clérigo; y por el c. 1398 §2 del texto reformado todos los delitos de índole sexual, salvo la excepción señalada, hasta aquí mencionados (en los cuales la comisión es de un clérigo) lo son también cuando el autor es un miembro no clérigo (mujer o varón) de un instituto de vida consagrada (IVC) o una sociedad de vida apostólica (SVA), o es «cualquier fiel que goce de una dignidad o ejercite un oficio o una función en la Iglesia ${ }^{48}$. La disposición extiende sus efectos a los nuevos supuestos que, como se ha ido viendo, han sido integrados con los anteriores en los cc. 1395 §3 y 1398 §1; por lo cual, todos ellos aparecen directamente tipificados en el derecho codicial no sólo cuando el autor es un clérigo sino también en estos otros $\operatorname{casos}^{49} \mathrm{Al}$ endurecimiento penal que comporta el nuevo LVI con respecto al CIC83 por la aparición de nuevos delitos, se une el que genera el agravamiento de las penas establecidas para los que ya están tipificados ${ }^{50}$.

48 No se especifica que el miembro de IVC o SVA al que sea refiere no es clérigo, pero aunque hubiera sido mejor hacerlo, se ha de entender que es así (los miembros clérigos, obviamente, están comprendidos en los casos en que el autor es un clérigo).

49 No ocurre lo mismo con el delito contra el sexto mandamiento cometido públicamente, pues ya se ha dicho que está en el c. 1395 \$2.

50 Como hemos visto, son los casos en que un clérigo comete abuso sexual a un menor o equiparado o el delito de pedo-pornografía. Para ellos, el art. 6 §2 de las normas de 2010 establece una pena acorde a la gravedad del delito, sin excluir la expulsión del estado clerical; y el c. 1398 §1 del nuevo LVI establece la «privación de oficio y otras penas justas, sin excluir, si el caso lo requiriese, la expulsión del estado clerical». Se añade, pues, la imposición preceptiva de la privación de oficio e incluso de otras penas, asegurando un nivel de penalización que hasta ahora podría no darse. En cambio, para los supuestos ya tipificados de abuso del clérigo con violencia, amenazas o públicamente, se mantiene la misma pena: «penas justas, sin excluir a expulsión del estado clerical» (c. 1395 \$2 y 3). Por completar esta cuestión de la pena establecida indicando la de los nuevos delitos, hay que señalar, primero, que la del c. 1398 §1 se establece también para los de abuso a persona vulnerable, implicación o inducción a un menor o equiparado o persona vulnerable, y de imágenes pornográficas con persona equiparada; todos ellos, cuando el autor es un clérigo. En segundo lugar, para los supuestos de igual autoría de abuso de autoridad y el tipo general (c. 1395 §3) la pena es la misma que para los de violencia, amenazas y públicamente. Finalmente, para todos los casos de los cc. 1395 §3 y 1398 §1, pero cuando el autor es «cualquier fiel que...» o un miembro no clérigo de IVC o SVA, el c. 1398 §2 del nuevo 
La extensión de los tipos penales a los supuestos de autoría por miembros no clérigos de IVC y SVA (por tanto, no en el delito cometido públicamente) tiene un claro precedente en VELM. En efecto, salvo el tipo residual, al definir los casos a los que se refieren sus disposiciones, el m. p. menciona de una $\mathrm{u}$ otra manera todos estos supuestos especificando (art. 1) que hacen referencia tanto al caso en que el autor es un clérigo, como al supuesto en que sea un miembro no clérigo de IVC o SVA. No recoge el caso en que el autor sea laico/a, pero ya vemos que el nuevo LVI sí lo incluye en algunos supuestos («cualquier fiel que...») $)^{51}$.

El texto reformado pone fin a una carencia que se detectaba en VELM. El m. p. denomina «delito» a todos los supuestos de índole sexual a los que refieren sus disposiciones (entre los cuales no están, como se acaba de ver, los que tienen como autor a un laico/a), tanto a los que ya estaban tipificados con anterioridad como a los que no; pero para estos últimos omitió, entre otras cosas, establecer una pena. Esta omisión hace que no quede nada claro si a partir de la entrada en vigor del m. p., en 2019, se daban realmente las condiciones necesarias para poder dar a esos supuestos aún no tipificados el tratamiento penal previsto para los delitos (abrir un proceso penal, imponer una pena, etc.). Afortunadamente, la cuestión queda solventada para los casos que se den a partir de la entrada en vigor del nuevo LVI, pues todos ellos (como procede hacer en un genuino tratamiento penal de las cosas) tendrán establecida las correspondientes penas ${ }^{52}$.

LVI establece que «sea castigado según el c. 1336 §§2-4, y con el añadido de otras penas en proporción a la gravedad del delito».

51 Sobre la extensión a algunos laicos cabe encontrar las mismas razones que se exponen en la nota 18.

52 Para una opinión contraria a que VELM permitiera ese tratamiento penal, cf. José Luis Sánchez-Girón. “El «motu proprio» «Vos estis lux mundi»", 682-687. Habrá quien sostenga una posición contraria, pero para una que presenta coincidencias, cf. Rella Ríos. "El abuso sexual”, 33-36. Sólo para el caso concreto de la pedo-pornografía cometida por un clérigo con imágenes de menores que tengan entre 14 y 18 años (el supuesto tipificado al aparecer el m. p. era únicamente el de imágenes de menores de 14 años, en las normas de 2010), el problema quedó resuelto mediante el rescripto de 17-12-2019 al que ya se ha hecho alusión, pues al integrarlo en el art. $6 \$ 1.2$ de las normas de 2010 quedó establecida una pena para este supuesto (la que ya estaba en el art. 6 \$2 para el caso de imágenes de menores de 14 años) al tiempo que adquirió la condición de delito reservado a la CDF. Esto daba motivos para pensar que, a pesar de que VELM lo denominara «delito», este supuesto no era susceptible del tratamiento penal que se da a los delitos hasta que apareció el rescripto; y lo mismo 
En cuanto a la condición o no de delito reservado a la CDF de los nuevos delitos, ante las dudas generadas por VELM para los supuestos aún no tipificados que recogía al no prestar atención alguna a este punto $(\dot{c}$ se pretendía que fueran delitos reservados los casos de abuso de menores cometidos por quien no es clérigo?, ¿pasaban a serlo los supuestos de abuso a persona vulnerable y abuso de autoridad cuando el autor es clérigo?, etc.), siempre será un planteamiento seguro considerar que sólo tienen esa condición los delitos integrados en las normas de 2010 (contando, obviamente, con las modificaciones que puedan ir teniendo $)^{53}$.

cabía pensar desde la promulgación del m. p. en adelante para los demás supuestos recogidos en él (e igualmente denominados «delito») que no estaban tipificados con anterioridad, pues, a diferencia del caso anterior, nunca se dio paso alguno que estableciera para ellos una pena en concreto hasta el nuevo LVI. Todo esto daba razones en favor de considerar que VELM, a pesar de emplear el término «delito», no tenía verdaderas pretensiones de tipificar nuevos supuestos delictivos concretos; o que, si las tenía, abordó este propósito con serias deficiencias (obviamente, sí pretende que sus disposiciones, relativas muy especialmente a garantizar que se informe a las autoridades sobre casos de índole sexual, se apliquen a todos los supuestos que contempla, estuvieran o no tipificados en ese momento). Sin embargo, los nn. 5 y 6 del vademécum ensombrecieron esta interpretación; y se podría decir que, lamentablemente, queda oscura. Más en concreto, el n. 6 aplica el término «delito» al supuesto de pedo-pornografía con imágenes de menores entre 14 y 18 años, pero no sólo para los casos posteriores al rescripto de 2019 (que ya sin duda lo tipificó) sino también para los anteriores al mismo y posteriores a VELM (señalando que no son competencia de la CDF); y el n. 5 emplea «tipo delictivo» de manera general y con referencia en particular al supuesto de abuso sexual a un «adulto vulnerable», que está en VELM y no estaba tipificado en ese momento. Esto hace pensar que, para el vademécum, desde la aparición del m. p. son susceptibles del tratamiento penal que se da a los delitos todos los casos mencionados en él que no estaban ya tipificados, por el mero nominalismo de que los llame «delito" y con independencia de que después se hubiera establecido o no para ellos una pena en concreto. Así, p. ej.: casos de abuso de autoridad o con persona vulnerable, o cualquier supuesto de autoría por parte de un miembro no clérigo de IVC o SVA, acaecidos entre la aparición de VELM y el nuevo LVI ¿pueden y podían ya ser tratados como delito sólo porque el m. p. les aplica el término «delito»? Se diría que para el vademécum la respuesta es afirmativa, pero aún cabe sostener que no es una cuestión clara. Para un interesante trabajo que señala y lamenta diversas inconsistencias en recientes documentos normativos de la Iglesia, cf., Geraldina Boni. La recente attività normativa eclesiale. Finis terra per lo ius canonicum? Mucchi Editore, 2021 (127-137 para algunas observaciones referidas a VELM).

53 Con esto queda que entre los delitos de índole sexual sólo están reservados a la CDF los cometidos por un clérigo de abuso sexual de un menor o equiparado, y el de pedo-pornografía. Salvo error de interpretación, los nn. 1-6 del vademécum vendrían 
VELM recoge otro supuesto (art. 1b) referido que las autoridades de la Iglesia eludan las actuaciones que debe llevar a cabo cuando tienen información sobre los casos de índole sexual contemplados en el propio m. p., o se interfiera en las que estén desarrollándose. Hay quien piensa que habría de considerarse como un tipo penal específico (que podría denominarse «encubrimiento») $)^{54}$; pero es razonable considerar que esta acción u omisión ya está comprendida en el delito relativo al ejercicio de la autoridad del c. 1389 del CIC83, tanto si se da de manera deliberada (§1), como si es fruto de una negligencia grave que además causa escándalo o daño ajeno $(\$ 2)^{55}$. De hecho, en algún momento se planteó que fuera el cauce para dar tratamiento penal a la manera incorrecta con que las autoridades de la Iglesia enfocaron los casos de abuso sexual a menores de edad cometidos por un clérigo ${ }^{56}$. Por otro lado, el m. p. del

a corroborar que los demás delitos (entre ellos, todos los que tienen por autor a quien no sea clérigo) no son reservados a la CDF, poniendo especial atención en clarificar que no lo son los supuestos con persona vulnerable (n. 5). No obstante, en el caso de las imágenes pornográficas puede subsistir una duda sobre el caso en que sean de una persona equiparada al menor. Como ya se ha dicho, el nuevo LVI lo incluye explícitamente como delito; pero las normas de 2010 no lo recogen de esta manera, ni con el rescripto de 2019 ya mencionado. Se podría pensar que, aun a falta de esa mención explícita, es un supuesto reservado a la CDF (y tipificado desde las normas 2010) por el mismo hecho en sí de que se trata de personas equiparadas al menor; pero ante la mención explícita en el nuevo LVI y la ausencia de la misma en las normas de 2010, convendría alguna aclaración oficial. Un razonamiento análogo se podría hacer con el caso de imágenes pornográficas de persona vulnerable: el nuevo LVI no lo recoge expresamente como delito, pero si es una persona que merece igual tutela que el menor y el equiparado, se podría pensar que, aun a falta de esa mención explícita, sí es delito. Quizá las aclaraciones oficiales podrían pronunciarse también sobre esto. La alternativa de que ambos supuestos sean delito haría valer que se asocian en derechos a casos sí mencionados (al menor, al menor y al equiparado), pero con eso pierde valor el hecho de que un supuesto así esté mencionado o no expresamente, y eso genera una incómoda inseguridad jurídica que siempre es mejor evitar.

54 Cf. Christoph Strack. "Las medidas de la Iglesia en casos de abuso llegan tarde y se quedan cortas”. DW.com. Visitado el 18 de octubre de 2021, https://www. dw.com/es/las-medidas-de-la-iglesia-en-casos-de-abuso-llegan-tarde-y-se-quedancortas/a-48695433

55 Algunos análisis del canon apoyarían este planteamiento, cf. p. ej., Pighin, 439-443.

56 Cf., p. ej., Damián Astigueta. "La persona e i suoi diritti nelle norme sugli abusi sessuali”. Periodica 93 (2004): 644; Peter Steinfels. A people adrift. New York-London: Simon and Schuster, 2003, 46. 
papa Francisco Como una madre amorosa, de 4 de junio de 2016, ya había abordado esta cuestión de manera más concreta ${ }^{57}$.

\subsection{OtRos NUEVOS DELITOS}

Destaca en el nuevo LVI la incorporación de delitos en materia económica que no están tipificados de manera específica en el CIC83. Están en el c. 1376. Con el primero de ellos se tipifica en el §1.1 la sustracción de bienes eclesiásticos, y también impedir que sean percibidos sus frutos, además de dar la condición de delito en el §1.2 a la enajenación de estos bienes —único supuesto delictivo de este tipo en el CIC83 (c. 1377)—y a realizar sobre ellos otros actos de administración, siempre que para una cosa u otra la validez o licitud requiera realizar una consulta, u obtener un consenso, o disponer de una licencia o atenerse a otro requisito impuesto por el derecho, y se llevan a cabo sin cumplir la condición de que se trate ${ }^{58}$. El §2 establece una pena también para la administración de los bienes eclesiásticos que "se haya demostrado gravemente negligente», contrarrestando el carácter tan amplio y genérico de este tipo residual con una mención específica a los supuestos del $\$ 1.2$ cuando se llevan a cabo con «culpa grave». Esto llama la atención porque viene a ser el único caso de este tipo junto al que ya está en el c. 1389 §2 del CIC83 (c. 1378 §2 en el nuevo LVI). Esta cuestión ha de relacionarse con el c. 1321 §3, según el cual, quien no incurre en un delito de manera deliberada (dolo) sino por omisión de la debida diligencia (negligencia o culpa grave), sólo queda sujeto a la pena establecida si la ley o el precepto así lo disponen. Este sería el caso del c. 1376 §2, que en alguna medida refleja el endurecimiento penal del nuevo LVI con respecto al CIC83 por cuanto añade un caso más de comisión culposa punible ${ }^{59}$.

57 Para un trabajo sobre este m. p., y su posible colisión con el c. 1389 del CIC83, cf. José Luis Sánchez-Girón. "El m. p. «Como una madre amorosa» a la luz de la normativa codicial”. Estudios Eclesiásticos 91, núm. 359 (2016): 843-860.

58 Los bienes que tienen la condición de «eclesiásticos» son los contemplados en el c. $1257 \S 1$. La necesidad de cumplir con requisitos como los que menciona el c. 1376 \$1.2 se puede ver en diversos cánones del Libro V como, p. ej., el 1277, 1291, 1292 y 1295.

59 El enfoque que da el c. 1321 a la comisión por negligencia puede considerarse como un rasgo de benignidad penal con respecto a otros ordenamientos jurídicos, cf. 
Seguramente, aquí la legislación del Estado Ciudad del Vaticano ha jugado de nuevo un papel de impulso e inspiración, pues es profusa la renovación y actualización legislativa que allí se ha dado en materia económica durante los últimos años. Se han abordado, entre otras, cuestiones relativas a la transparencia y control de los contratos públicos (1 de junio de 2020) o al abuso de mercado (28 de septiembre de 2018), y se han perfilado las disposiciones penales en materia de delitos económicos (p. ej., en los art. 8 y 28 de la Ley IX, de 11 de julio de 2013) ${ }^{60}$.

El c. 1393 §2 integra un nuevo tipo penal de índole económica: «el clérigo o religioso que, aparte de los casos ya previstos por el derecho, comete un delito en materia económica». El tipo penal es específico en cuanto al autor del delito, y al tiempo es muy amplio y genérico en lo que se refiere a la conducta o acción tipificada. El canon comporta un tratamiento penal más riguroso para los clérigos y religiosos en el terreno económico, tipificando sólo para ellos actuaciones en este ámbito que no estén ya tipificadas en otros delitos. Por otro lado, el canon también tipifica el caso del clérigo o religioso que «viola gravemente las prescripciones del c. $285 \S 4$ », el cual se refiere a que los clérigos (y es aplicable a los religiosos/as según el c. 672) deben obtener licencia de la autoridad eclesiástica competente, o al menos consultarle, para llevar a cabo ciertas funciones o actos de índole económica. Podría considerarse que este tipo penal completa el del c. 1393 §1 (c. 1392 en el CIC83) para acabar de diseñar un amplio espacio de actuaciones de los clérigos y los laicos en el terreno económico que se consideran delictivas ${ }^{61}$.

José Luis Sánchez-Girón, “Penas medicinales y expiatorias”, 273-276. El enfoque se mantiene en el nuevo LVI, pero vemos que se amplían los casos en que se aplica la pena atendiendo a la necesidad de hacer mención específica de ello.

60 Para esta Ley, las otras normativas mencionadas y otras más en esta materia, se puede consultar la información ofrecida en internet por el Estado Ciudad del Vaticano (sección Stato e governo), cf. Stato della Città del Vaticano, consultado el 18 de octubre de 2011, https://www.vaticanstate.va/it/

61 El c. 1393 §1 se refiere al ejercicio ilícito del comercio y la negociación por parte de los clérigos o religiosos, lo cual se conecta con la prohibición de realizar una u otra cosa sin licencia (c. 286 para los clérigos, c. 672 para los religiosos). El sentido de añadir ahora el tipo penal del c. 1393 \$2 habría que entenderlo bajo la perspectiva de que las actuaciones referidas en el c. $285 \$ 4$ (administrar patrimonios de laicos, desempeñar "oficios seculares que lleven consigo la obligación de rendir cuentas», salir fiador, asumir deudas, etc.) no tienen por qué ser exactamente lo que se entiende por ejercicio del comercio o la negociación. 
Los §§4-6 del c. 1371 del nuevo LVI introducen tres nuevos delitos en el ordenamiento penal canónico. El primero de ellos (§4) se refiere a la violación del secreto pontificio; una obligación de secreto que recae sobre quienes intervienen en asuntos llevados a cabo por la Santa Sede. Dada la intensa actividad penal que en los últimos años se encauza a través de las normas para delitos reservados a la CDF, el canon puede tener especial conexión con el art. 30 de las normas de 2010, donde se dispone que estas causas «están sujetas al secreto pontificio» ${ }^{62}$. El segundo (§5) tipifica el incumplimiento del deber de ejecutar una sentencia ejecutoria o un decreto penal ejecutorio, cuestión que puede conectarse con la exigencia de llevar a cabo esta ejecución contemplada en cánones como el 1653 y el 1363, y cuyo incumplimiento podría acarrear ahora la comisión de un delito. Finalmente, el §6 tipifica la omisión del deber que haya sido establecido en la ley de comunicar la información que se tenga sobre la comisión de un delito. En este caso, el canon puede ponerse en conexión con el art. 3.1. de VELM como un supuesto concreto y reciente de obligación impuesta por la ley, pues en él se dispone que los clérigos y miembros de un IVC o SVA «tienen la obligación» de informar «sin demora» a la autoridad competente de lo que sepan acerca de los «hechos mencionados en el artículo 1» (es decir, de los distintos supuestos de índole sexual, y de indebido tratamiento de los mismos por parte de la autoridad, a los que el m. p. refiere sus disposiciones).

Un nuevo delito que puede generar alguna confusión es el del c. $1379 \S 4$ del texto reformado, en el cual se tipifica el hecho de «administrar

62 No obstante, el art. 30 integra el supuesto de comisión por negligencia; cosa que, según ya se ha comentado sobre este tipo de comisión, no se daría con el c. $1371 \S 4$ para otros espacios de actuación sujetos a secreto pontificio. Sobre el mismo, cf. Ioannes card. Villot, Secretarius Status. Instructio Secreta continere, de secreto pontificio, de 4 de febrero de 1974. Santa Sede. Consultado el 18 de octubre de 2021, https://www.vatican.va/roman_curia/secretariat_state/card-villot/documents/ rc_seg-st_19740204_secreta-continere_lt.html. Además, habría que poner fuera de esta obligación las causas referidas a los delitos reservados a la CDF de abuso sexual de un menor y de pedo-pornografía cometidos por un clérigo (art. 6 de las normas de 2010), así como el resto de los supuestos contemplados en VELM, pues es lo que se dispuso a poca distancia del m. p., cf. Pietro Card. Parolin, Secretario de Estado. Instrucción sobre la confidencialidad de las causas, de 6 de diciembre de 2019, Santa Sede. Consultado el 18 de octubre de 2021, https:/www.vatican.va/roman_curia/ secretariat_state/2019/documents/rc-seg-st-20191206_rescriptum_sp.html. De este modo, el c. $1371 \S 4$ nace ya con un importante recorte en su espacio de aplicación. 
deliberadamente un sacramento a quienes tienen prohibido recibirlo». Éste es un caso donde se ha tomado como fuente el CIC17, recuperando este delito, allí contemplado en el c. 2364, que no pasó al CIC83. La duda puede venir en torno a qué clase o nivel de prohibición es la que comprende el tipo penal (¿se trata, p. ej., de casos de communicatio in sacris prohibida - lo cual podría ser un solapamiento con el c. 1381- o de los divorciados que contraen luego matrimonio civil?); y se ha de entender que el canon hace referencia a prohibiciones establecidas de manera específica en un auténtico acto jurídico, como puede ser la imposición de una pena que prohíba recibir los sacramentos (concretamente, cc. 1331 y 1332$)^{63}$.

Otros casos en los que el nuevo LVI retoma delitos del CIC17 que no entraron en el CIC83 son los del c. 1377 \$2 y 1388 §2 (respectivamente, cc. 2408 y 2374 del CIC17). El primero de ellos se refiere a quien «en el ejercicio de un oficio o cargo pide una oferta mayor de lo establecido o sumas añadidas o algo en beneficio propio». Esto puede ponerse en conexión, p. ej., con el c. 1264, donde se dispone que la reunión de los obispos de una provincia eclesiástica determine las ofrendas que se han de hacer por la administración de los sacramentos y sacramentales, así como las tasas asociadas a determinados actos de potestad ejecutiva. Cabría pensar que este tipo de acciones están ya comprendidas en el delito de abuso de potestad, oficio o cargo del c. 1378, y que se ha considerado positivo singularizar este supuesto en un delito específico. Por su parte, el c. 1388 §2 tipifica el acceder al sacramento del orden estando afectado por una irregularidad que voluntariamente se oculta ${ }^{64}$.

Finalmente, un nuevo delito referido específicamente al clero está en el c. 1392 §1 del texto reformado: «El clérigo que abandona voluntaria e ilegítimamente el ministerio sagrado durante seis meses continuados, con intención de sustraerse a la competente autoridad de la Iglesia». Este tipo de casos, junto a otros, había sido abordado en 2009 mediante unas facultades concedidas a la Congregación para el Clero que permitían al dicasterio (Facultad III y punto 8) tratar casos de abandono del ministerio (previamente instruidos por el obispo competente) y proveer para ellos

63 Una vez más, esto lo explicaron Mons. Iannone y Mons. Arrieta en la rueda de prensa de 1 de junio de 2021 (ver la nota 42), a preguntas que les hicieron, cf. https:// www.youtube.com/watch?v=3hNjfpskjOs\&t=370s (minutos 51-53 y 57-60 del vídeo).

${ }_{64}$ Para las irregularidades a las que se refiere el canon, ver los cc. 1044-1049. 
incluso la salida del estado clerical del clérigo en cuestión; medida que figura como posible pena, para los casos más graves, entre las establecidas ahora en el canon ${ }^{65}$. Las facultades se referían al supuesto en que el abandono se prolongase por más de 5 años seguidos, lo cual implica que el c. 1392 §1 comporta un tratamiento mucho más riguroso de estos casos.

\section{RENOVADA CALIFICACIÓN DE LOS DELITOS}

Un aspecto interesante del nuevo LVI es el diseño de otro sistema de agrupación y calificación de los delitos a través de los siete Títulos de la Parte II, dedicada a ir recogiendo los distintos delitos tipificados en el CIC estableciendo la pena en cada caso (se suele hablar de "parte especial» dentro del derecho penal sustantivo). Una novedad relevante es haber reunido los delitos contra los sacramentos en una misma agrupación, que es el Título III. En él se encuentran ahora delitos que en el CIC83 están concebidos como contrarios a las funciones eclesiásticas, o agrupados con otros relativos al ejercicio de oficios o cargos y de la potestad. Sin duda están mejor presentados como delitos contra los sacramentos (atentada eucaristía, absolución u ordenación, otros casos de simulación de un sacramento, simonía, violación del sigilo sacramental, etc.). Hay delitos que pasan a estar catalogados como contrarios la fe (a la religión en el CIC83) en lugar de contrarios a las autoridades de la Iglesia (p. ej., la profanación de una cosa sagrada, o enseñar doctrinas condenadas), otros que cambian en sentido contrario (perjurio) y hay diversos cambios más entre unas calificaciones y otras.

Merece ser destacado el cambio que se produce con el abuso sexual a menores de edad, por ser una recalificación que se venía demandando. En el CIC83, donde la autoría se asigna sólo a los clérigos (sacerdotes y diáconos), está entre los delitos contra las obligaciones especiales (Título V); lo cual hace claramente referencia a que atenta contra lo que se espera de un clérigo, y más en concreto el celibato sacerdotal. Se ha repetido que esta calificación incidía negativamente en el adecuado tratamiento de estos casos, enfocándolos bajo la perspectiva de que el bien

${ }^{65}$ Cf. Congregatio pro Clericis. "Carta circular por la que se comunican las facultades especiales concedidas para la expulsión de los clérigos del estado clerical”, de 18 de abril de 2009. REDC 67 (2010): 391-400. 
jurídico protegido es la dignidad del sacerdocio (del estado clerical en general) y no las víctimas que ya lo han sido y las potenciales (los menores en su conjunto). En clara respuesta a esto, el delito pasa a estar integrado entre los que son contrarios a la vida, la dignidad y la libertad, en el Título VI ${ }^{66}$. Aquí se encuentran ahora en el c. 1398 §1 (como se ha ido viendo) los delitos de abuso sexual a un menor, persona equiparada o vulnerable, de implicación o inducción a estas mismas personas para exponerse en exhibiciones pornográficas, de pedo-pornografía y de imágenes pornográficas de un equiparado; en todos los casos, tanto si el autor es un clérigo como, por la remisión del c. 1398 §2 al c. 1398 §1, si es un miembro no clérigo (varón o mujer) de IVC o SVA, o un seglar (laico/a) que tenga alguna dignidad, oficio o función en la Iglesia. Dado que el c. 1398 §2 se remite asimismo al c. 1395 §3, habrá que entender que, cuando tienen esa misma autoría, los supuestos de abuso sexual con violencia, amenazas, abuso de autoridad y el tipo residual también están entre los delitos contra la vida, la dignidad y la libertad.

Es de esperar que este cambio tan demandado dé los frutos pretendidos, en el marco de una creciente conciencia de la Iglesia y sus autoridades de que el enfoque adoptado es más justo y acertado y da mejor cauce a la voluntad cada vez mayor de potenciar la atención a las víctimas $^{67}$. Lo que puede generar extrañeza es que los abusos sexuales con violencia, amenazas o abuso de autoridad y el tipo residual del c. $1395 \S 3$ hayan quedado, cuando el autor es un clérigo, entre los delitos contra las obligaciones especiales del Título V, supuesto que el canon está en ese

${ }^{66}$ Sobre los planteamientos que se venían dando en esta misma línea con anterioridad al LVI, cf. Marcelo Gidi. "Lo statuto penale del minore nel can. c. 1395 § 2: analisi critica alla luce dei presupposti dottrinali della teoria penale del bene giuridico". Periodica 108 (2019): 5-7.20-24.30. Por otra parte, se trata de la misma línea que ha ido adoptándose en los ordenamientos estatales, cf. Enrique Orts Berenguer y Carlos Suárez-Mira Rodríguez. Los delitos contra la libertad e indemnidad sexuales. Valencia: Tirant lo Blanch, 2001, 16-21. También en este ámbito se reflexiona en torno a la más adecuada calificación del bien jurídico protegido en el abuso sexual, cf. Myriam Cabrera Martín. La victimización sexual de menores en el Código Penal español y en la política criminal internacional. Madrid: Dykinson, 2019, 37-74.

67 Para una panorámica del creciente esfuerzo de la Iglesia por mejorar su manera de abordar esta delicada cuestión, cf. Rafael Felipe Freije. "Respuesta eclesial y canónica a los abusos sexuales de menores bajo el impulso de J. Ratzinger, prefecto y papa”. Tesis doctoral en Derecho Canónico, Universidad Pontificia Comillas, 2019, 41-112. 
Título y que la remisión al mismo en el c. 1398 §2 (Título VI) es para tipificar los casos en que el autor es un laico o un miembro no clérigo de IVC o SVA. Es como estar transmitiendo que no se consideran también atentados contra la dignidad y la libertad, y que en estos supuestos sí es acertado enfocar el caso bajo la perspectiva de que el bien protegido es la dignidad del estatus clerical y no la de la víctima. Puede que esto no sea del todo fácil de asimilar ${ }^{68}$.

\section{NUEVO TRATAMIENTO DE LA PRESCRIPCIÓN Y OTRAS NOVE- DADES RELEVANTES}

Un punto importante que experimenta cambios relevantes en el nuevo LVI es la prescripción de la acción criminal, en el c. 1362; una cuestión de derecho sustantivo pero muy conectada con el derecho procesal ${ }^{69}$. Se mantiene el principio general de que la acción prescribe a los 3 años

68 Como ya se ha señalado, el delito contra el sexto mandamiento del decálogo cometido por un clérigo públicamente está en el c. 1395 §2 del CIC83 junto a los supuestos de abuso sexual con violencia, amenazas o un menor; y en el nuevo LVI ha quedado en el canon que también es el 1395 §2, pero como único caso allí recogido y, por tanto, separado de los otros dos. Con ello resulta que, a diferencia de ambos supuestos, no hay delito si esta acción la lleva a cabo un laico o un miembro no clérigo de IVC o SAV, y no se recoge entre los delitos contra la vida, la dignidad y la libertad, sino en los contrarios a las obligaciones especiales (entiéndase, en este caso, las del clérigo). En este supuesto todo ello resulta más comprensible. Se puede entender que no sea concebido como un abuso (y que por ello se haya separado del delito con violencia o amenazas) considerando que, si ha de ser un tipo penal distinto de otros, se trata de casos en que la persona que lleva a cabo la acción con el clérigo no es ni un menor, ni una persona equiparada o vulnerable, y en los cuales no ha habido violencia, ni amenazas ni abuso de autoridad. Lo más verosímil es que se trate de una acción consentida (como en los delitos del c. 1395 §1) que en el fondo no atenta contra la libertad, y en la cual es razonable identificar la gravedad en que la haya realizado un clérigo y, además, públicamente.

69 La acción criminal es el conjunto de actuaciones procesales previstas para ser llevadas a cabo por la autoridad de la Iglesia ante la posibilidad de que se haya cometido un delito, orientadas a conocer la verdad de los hechos y sus circunstancias a través de un proceso penal que, conforme al derecho aplicable, culmine con una resolución justa a partir de todo ello (para una definición de la acción criminal, cf. Hanna Alwan. "Acción criminal”, en Diccionario General... Vol. 1, 112). Que prescriba al cabo de un tiempo significa que en ese momento la autoridad de la Iglesia pierde el derecho a llevar a cabo esas acciones, y no podrá abrir un proceso penal, cf. Federico 
contados desde la comisión del delito, pero aumenta el plazo en los supuestos especiales que, como excepción, tienen previsto otro distinto; y se incrementa el número de los mismos sin prescindir de ninguno de los que hay en el CIC83. Salvo para los delitos del c. $1398 \S 1$ (pues se les da otro tratamiento que enseguida veremos), el plazo en estos casos especiales es de 7 años, frente al de 5 años que se da en el CIC83 a las excepciones al principio general de 3 años. Por tanto, dejando aparte los delitos del c. 1398 §1 que también sean excepción en el CIC83, el tratamiento penal se endurece con una ampliación de 2 años para los demás casos especiales que recoge el CIC $83^{70}$. Hay delitos que están en el CIC sin ser casos especiales, pero pasan a serlo; con lo cual en ellos el endurecimiento es de 4 años al pasar el plazo de prescripción de 3 a 7 años ${ }^{71}$. Finalmente, entre los casos de excepción del LVI hay delitos que no lo eran en el CIC83, con lo cual aparecen directamente en el derecho penal de la Iglesia con un plazo de prescripción de 7 años ${ }^{72}$.

Aznar. "Los «delicta graviora» reservados a la Congregación para la Doctrina de la Fe. Texto modificado (2010)”. REDC 68 (2011): 303.

70 Serían los cc. 1394 (atentado matrimonio del clérigo o del religioso/a de votos perpetuos; mismo canon en el CIC83), 1397 (homicidio, rapto o retención con violencia o fraude, mutilación o graves heridas y aborto; cc. 1397 y 1398 en el CIC83) y 1395 (c. 1395 en el CIC83, salvo el caso de abuso de autoridad, que no está en él, y el del menor de edad, que, como hemos anticipado, experimenta un cambio distinto al pasar al c. 1398 §1). En esta cuestión de la prescripción, el supuesto del pecado contra el sexto mandamiento cometido públicamente por un clérigo sí tiene el mismo tratamiento que los casos de comisión con amenazas y violencia, de los cuales ya hemos visto que se separa pasando a tener un enfoque distinto en otros aspectos.

71 Son los delitos de corrupción (c. 1377, c.1386 en el CIC83), abuso de autoridad y ejercicio negligente de la misma (c. 1378, c. 1389 en el CIC83), comercio o negociación llevada a cabo ilícitamente por un clérigo o un religioso/a (c. 1393 §1, c. 1392 en el CIC83) y enajenación de bienes eclesiásticos sin licencia (c. 1376 §1.2, c. 1377 en el CIC83).

72 Se trataría de los delitos económicos del c. 1376 (salvo el supuesto de enajenación, que ya está en el CIC83) y el delito de solicitar una oferta mayor de la establecida o sumas añadidas, del c. 1377 §2; el cual de alguna manera también tiene un carácter económico. Se podría pretender matizar el planteamiento expresado sobre estos delitos considerando que ya están en el CIC83 por responder al tipo penal de su c. 1389 (como casos específicos de este tipo residual que ahora se singularizan); con lo cual, bajo esta interpretación, serían otros supuestos más que experimentan el endurecimiento de pasar de un plazo de 3 años para la prescripción de la acción criminal, a uno de 7 años. 
Como se ve, las novedades en materia de prescripción de la acción criminal comportan un tratamiento más riguroso que el CIC83, y contribuyen a ese rasgo de endurecimiento penal que hemos ido viendo en otros aspectos del nuevo LVI y que cabe asignar en general al conjunto del mismo. Cabría destacar la presencia que cobra en los delitos económicos este nuevo y más riguroso tratamiento de la prescripción ${ }^{73}$.

En cuanto a los delitos del c. 1398 §1 del nuevo LVI, el c. 1362 les asigna un plazo de 20 años para la prescripción de la acción criminal. Entre ellos están los delitos reservados a la CDF en el art. 6 de las normas de 2010 (contando con el rescripto de diciembre de 2019, aquí mencionado anteriormente) de abuso sexual cometido por un clérigo con un menor de edad o equiparado, y de pedo-pornografía cometido asimismo por un clérigo, para los cuales las normas de 2010 establecen, como para todos los delitos reservados, ese mismo plazo. Ahora bien, el nuevo LVI no recoge un matiz sumamente importante que sí está en esas normas (art. 7 §1), y que resulta evidente que ha de mantenerse: en el abuso a un menor de edad (por definición, el equiparado es mayor de 18 años) el cómputo de los 20 años no comienza desde la comisión del delito, sino desde que el menor cumpla 18 años $^{74}$.

En los demás delitos del c. 1398 §1, los de abuso sexual y de implicación o inducción a la exposición o exhibición pornográficas cometidos por un clérigo con una persona vulnerable no están entre los delitos reservados a la CDF, por lo cual no hay nada en las normas de 2010 que les afecte en materia de prescripción de la acción criminal. No siendo supuestos contemplados en el CIC83, cabría decir que se integran directamente en el nuevo LVI con un plazo de prescripción de la acción criminal de 20 años contados desde la comisión del delito. Lo mismo sería en los delitos del clérigo con un equiparado de inducción o implicación y de imágenes pornográficas, a menos que se considere que el primero es un supuesto específico de abuso sexual, en cuyo caso ya estaría tipificado desde las normas de 2010 y ese plazo de 20 años le habría sido asignado en ellas; y otro tanto pasaría con el segundo caso, si se considera que,

73 Baste cotejar las notas anteriores para verificar en ellas la presencia de este tipo de delitos.

74 El nuevo LVI evita la colisión con las normas de 2010 — con la problemática que esto comportaría de aplicación de la ley más favorable (c. 1313)—al mantener la disposición del c. 1362 \$1.1, según la cual los delitos reservados a la CDF se rigen en esta materia por sus propias normas. 
por equiparación con el menor, ya está tipificado en las normas de 2010 (en las que se tipificó la pedo-pornografía) ${ }^{75}$.

Otra novedad muy importante en el nuevo LVI es que el c. $1362 \S 3$ se pronuncia acerca de cuándo se deja de contar el plazo de prescripción, de manera que aun cuando se cumpla su tiempo después de ese momento, la acción criminal seguirá viva. Para el proceso judicial, el canon señala como ese momento el de citar al acusado (c. 1723), o el de su comparecencia de hecho antes de ser citado (c. 1507 §3) siendo en ella informado de que se ha presentado el escrito acusatorio (c. 1721 §1). La norma añade que la suspensión del cómputo se da por tres años, de modo que al cabo de los mismos, o antes en caso de quedar «interrumpida la suspensión» a causa de la cesación del proceso», se vuelve a contar el tiempo para la prescripción "que se añade al ya transcurrido». Para el proceso administrativo se dispone lo mismo, siendo el momento en que se suspende el cómputo el de dar a conocer al acusado la acusación y las pruebas (c. $1720.1)^{76}$. Una señalación clara y precisa como la que se hace ahora de una acción que, al llevarse a cabo, produce la suspensión del cómputo, es algo que se echa de menos en el CIC83. A falta de algo así, había diversas acciones que se proponían como generadoras de ese efecto ${ }^{77}$. Sin duda la aportación del nuevo LVI en este punto es muy valiosa.

75 Precisar el plazo de prescripción de la acción criminal establecido en la ley en el momento de la comisión del delito es importante, como lo es el momento en que el delito se tipificó (nota 42) por las consecuencias penales absolutamente distintas que tiene el hecho de que la acción tipificada haya tenido lugar antes o después de ese momento. Si cambia el plazo de prescripción, esto puede dar lugar a tener que abordar el caso desde la aplicación de un principio tan consagrado en derecho penal como es el de aplicación la ley más favorable

76 La alternativa a la opción de suspensión del cómputo que se ha tomado sería que, para el caso de retomarlo, en el momento de hacerlo se empieza a contar el plazo entero y no sólo lo que queda descontando el tiempo transcurrido hasta que se dejó de computar. La interrupción de la suspensión a la que se refiere el canon podría asociarse p. ej., con el c. 1520: «La instancia caduca cuando, sin que exista un impedimento, las partes no realizan ningún acto procesal durante seis meses», cf. Davide Cito. "La prescrizione in materia penale". En Processo penale e tutela dei diritti nell'ordinamento canonico, editada por Davide Cito, 226-227. Milano: Giuffrè Editore, 2005.

77 Cf. José Luis Sánchez-Girón. "Algunos interrogantes en la disciplina codicial sobre la prescripción de la acción criminal”. En «Iustitia et Iudicium». Studi di Diritto Matrimoniale e Processuale Canonico in onore di Antoni Stankiewicz, editada por Janusz Kowal y Joaquín Llobell, vol. 4, 2173-2183. Città del Vaticano: Libreria Editrice Vaticana, 2010. 
Para terminar este apartado vale la pena destacar algunas aportaciones del nuevo LVI que, en realidad, son principios muy consagrados en el derecho canónico y habrían de aplicarse incluso si no se reflejaran explícitamente en una ley. Por otro lado, frente al endurecimiento que comporta el texto reformado, son principios que juegan más en favor de los derechos del acusado.

Uno de ellos es la presunción de inocencia, explicitada en el c. 1321: «Toda persona es considerada inocente mientras no se pruebe lo contrario». A pesar de lo arraigado que está este principio, no han faltado numerosas manifestaciones en el sentido de que no se ha estado atendiendo adecuadamente ${ }^{78}$. Otros dos principios están en el c. $1342 \S 1$, y aparecen a propósito del proceso penal administrativo. Se trata del derecho de defensa y de la exigencia de certeza moral en las resoluciones finalmente adoptadas en los procesos. En realidad, el primero de ellos sí se encuentra en la regulación del proceso penal administrativo del CIC83 (c. 1720.1), pero también han abundado consideraciones apuntando a que, en su regulación y en la praxis, este proceso presenta importantes lagunas entre las que está una mayor fragilidad del derecho de defensa ${ }^{79}$. En cuanto a la certeza moral, para el proceso judicial el c. $1608 \S 1$ exige que el juez o tribunal la tenga sobre el asunto que debe dirimir para dictar cualquier sentencia, y esto sería aplicable en el proceso judicial penal (c. $1728 \S 1)^{80}$. También al administrativo, cosa que explicita el c. $1342 \S 1$ citando el c. 1680; y hay que valorarlo positivamente porque ha habido no pocas manifestaciones expresando

78 Cf. p. ej., Francisco Campos. "Derechos fundamentales del investigado y aplicación de medidas cautelares. Un estudio a partir del art. 19 de las «normas sobre delitos más graves»". REDC 74 (2017): 376-377, 383, 396-398.

79 Cf. Pighin, 546; Claudio Papale. Il processo penale canonico. Commento al Codice di Diritto Canonico Libro VII, Parte IV. Città del Vaticano: Urbaniana Universtiy Press, 2007, 71-72; Myriam Cortés. "La investigación previa en el proceso administrativo penal”. REDC 70 (2013): 525.

80 Según el art. 247 §2 de la Instrucción Dignitas connubii, la certeza moral «requiere que se excluya cualquier prudente duda positiva de error, de derecho y de hecho, aunque no desaparezca la mera posibilidad de lo contrario»: PCTL. Instrucción Dignitas connubii. Salamanca: Asociación Española de Canonistas (traducción del profesor D. Jesús Bogarín Díaz), 2005, 46. También, cf. Juan José García Faílde. Tratado de Derecho Procesal Canónico. Salamanca: UPSA, 2005, $322-324$. 
la necesidad de subrayarlo, lo cual viene a significar que se detectaba cierta debilidad en su aplicación en la práctica ${ }^{81}$.

\section{OBSERVACIONES FINALES Y CONCLUSIONES}

El nuevo LVI ha asumido algo que hubiera sido prácticamente inviable enfocar de otro modo: mantenerse en el rango de cánones que tiene en el CIC83, cc. 1311-1399, dejando que las modificaciones del texto (nuevas disposiciones, cambios de ubicación, etc.) se produzcan dentro del mismo y sin salir de él. De esta manera no se ha pretendido forzar una renumeración del resto de Código. Un problema puede venir cuando otras normas contengan remisiones a cánones del CIC 83 conforme a la numeración que tengan en él. Al menos se puede decir que en el Código son pocos los cánones que se remiten a otros del derecho penal ${ }^{82}$. Una normativa que tiene numerosas interrelaciones de este tipo con el LVI es la relativa a los delitos reservados a la CDF. Un buen número de veces las normas de 2010 incorporan como delito reservado uno que está en el CIC83, haciendo que la mención del canon correspondiente sea lo que integra en la norma el tipo penal y la pena. En realidad, apenas habrá una vez (remisión del art. 2 al c. 1364) en que esto se haga y no resulte que ahora remite a un canon del nuevo LVI que recoge un delito distinto que en el CIC83. No parece que este tipo de problema deba presentar graves dificultades que no se puedan no abordar fácilmente. Más enjundia tendría, p. ej., el caso de un delito cuya pena ha sido alterada en el nuevo LVI. Seguramente la aplicación del principio de la ley más favorable irá dando soluciones adecuadas cuando esto se presente. En todo caso, a salvo de una revisión más exhaustiva, no se ve que en el LVI haya cambios relevantes en las penas de delitos reservados ${ }^{83}$.

81 Cf., p. ej., Antonio Calabrese. “Comentario al c. 1720”, en Comentario exegético... vol. 4/2, 2080; M. Mosconi. "L'indagine previa e la l'applicazione della pena in via amministrativa". En Gruppo italiano docenti di Diritto Canonico, I giudizi nella Chiesa. Processi e procedure speciali, Quaderni della Mendorla 7, Milano: Glossa, 1999, 219.

82 Uno de ellos sería el c. 695 §1, que al establecer causas de expulsión de un instituto religioso se remite a los supuestos del c. 1395 §; el cual, como hemos visto, ha cambiado casi por completo.

83 Se da alguna alteración, p. ej., en el delito de atentada ordenación (art. 5 §1, 1379 §3, no está en CIC83) y en la violación directa del sigilo sacramental (art 4 §1.5, c. $1386 \S 1$, c. 1388 §1 del CIC83), en tanto que la pena establecida antes del nuevo LVI 
El texto reformado sí supone un avance en claridad y capacidad operativa de la redacción, aunque nunca habían de faltar puntos mejorables; p. ej., la posible colisión entre el c. 1347 §2 y el 1361 §4 en cuanto a la exigencia por el segundo de alguna reparación de los daños para considerar que hay cese de la contumacia (el c. 1347 \$2 admitiría la promesa seria de reparar). En la línea de esos dos objetivos también estaría la mayor concreción de las penas, reduciendo los márgenes de indeterminación que deja el CIC. Por esta vía se ha intensificado una clara evolución del cuadro penal hacia las penas expiatorias en detrimento de la presencia de las censuras. Esto supone dejar menos espacio en la Iglesia a la posibilidad de actuar en ella valores tan genuinamente cristianos y evangélicos como el arrepentimiento y el perdón, para los cuales las censuras son en principio un cauce más poderoso que las penas expiatorias. En todo caso, el refuerzo de estas últimas parece estar en consonancia con valores en alza en las sociedades, como el cumplimiento íntegro de las penas; y puede ser un buen momento para meditar hasta qué punto se han hecho realidad práctica en la Iglesia de los últimos tiempos esos valores cristianos a través de las penas medicinales, o qué posibilidades reales había y hay de hacerlo por predisposición, conocimiento y voluntad de la comunidad eclesial ${ }^{84}$.

Aparte de las modificaciones en la pena, los cambios en la prescripción y la tipificación de tipos penales más específicos que encajan en otros más genéricos que ya están tipificados pueden ser, como se ha tratado anteriormente, otra fuente de posibles casos (acaecidos antes del LVI y abordados después) que hayan de enfocarse bajo a perspectiva de aplicar la ley más favorable. Dado el endurecimiento general de las penas, la tendencia mayoritaria podría ser a la aplicación del CIC83 y no del nuevo LVI. Como hemos visto, el rigor penal se ha hecho mayor por diversos caminos: drástica reducción de las penas facultativas, endurecimiento de las consecuencias penales de las agravantes, menor benignidad ante la presencia de atenuantes en las penas ls, posibilidad general de imponer penas expiatorias al declarar o imponer una censura, extensión de

es la censura de excomunión, y por el c. 1335 §1 se da la posibilidad, que no ofrece el CIC83 en estos casos, de añadir penas expiatorias a las censuras cuando se impongan o declaren.

84 Cf. Alfonso Valsecchi. "Pena e perdono. Provocazioni interdisciplinari per la Teologia”. La Scuola Cattolica 135 (2007): 442; Julián Ríos. La prisión perpetua en España. San Sebastián: Gakoa Liburuak, 2013, 78-83. 
la suspensión a los laicos, integración de los mismos en algunos casos como autores de delitos que en el CIC83 sólo lo son cuando el autor es un clérigo, aparición de nuevas penas entre las cuales destacan las monetarias, mayor prestancia del precepto penal, etc. A tenor de lo que se ha ido tratando acerca de estos y otros puntos, se hace evidente que en nuevo LVI presenta un panorama penal de conjunto más riguroso y duro que el CIC83.

En realidad, esto sería la consecución de un objetivo que se vislumbraba a lo largo del proceso de elaboración del texto reformado, sin que haya faltado a lo largo del mismo algún movimiento hacia la suavización $^{85}$. Más novedoso con respecto al desarrollo del proceso, tomado en el conjunto de su larga duración, es la insistencia del texto final del LVI en la reparación de los daños, que seguramente es una creciente aspiración de la Iglesia en su voluntad de atender mejor a las víctimas de los delitos. También ha resultado más novedosa la presencia que ha cobrado finalmente la pena de privación de oficio, seguramente asociada a la también más novedosa tipificación de delitos que se dan en el ejercicio de oficios, cargos o funciones.

Este aspecto de la incorporación de nuevos delitos, sin eliminar ninguno que ya lo sea en el CIC83, es otra vía de endurecimiento. Dentro de ella cabe destacar los nuevos delitos de índole económica. Casi se podría decir que, junto a los delitos de índole sexual, son los campos en los que el cuadro de delitos presenta mayores novedades. En el caso de estos otros delitos, ha habido sin embargo un bagaje más intenso de muchos años anteriores abordando ese espacio delictivo; en particular, se deja sentir la huella reciente del m. p. VELM (2019), con el cual el nuevo LVI presenta una relación muy estrecha, aunque no falten novedades que no estaban claramente precedidas en el mismo; p. ej., la integración de laicos como autores de los delitos. El texto reformado sale al paso de puntos menos perfilados en el m. p. en el terreno penal. El tiempo dirá si han quedado espacios más inciertos (básicamente, los hechos sucedidos en el tiempo que medie entre ambos).

El nuevo LVI es fruto de un largo periodo de trabajo en el que ha habido una amplia labor de consulta a personas e instancias capaces de aportar luz. Se ha tomado inspiración de muchas fuentes: del CIC17, de

85 Cf. José Luis Sánchez-Girón. "Nuevos desarrollos en el proyecto de reforma del Derecho Canónico Penal”. REDC 76 (2019): 299-300, 310-312. 
las iniciativas de Estado Ciudad del Vaticano, de la legislación de la Iglesia de los últimos años, de las opiniones y valoraciones que los canonistas han compartido en publicaciones y foros diversos, del sentir de los fieles... En principio, da la sensación de que ha alcanzado un buen nivel en lo que se refiere a armonizar y atender a tantas cosas.

De nuevo, sólo el tiempo dirá con mayor certeza en qué medida el nuevo LVI haya sido un instrumento provechoso para la Iglesia. Como actitud de partida, seguramente vale la pena brindarle una buena acogida, conocerlo y aplicarlo. Ahora bien, una de las motivaciones para emprender la reforma fue la constatación de una frágil aplicación del derecho canónico penal por desconocimiento del mismo y por su dificultad; y la complejidad de este derecho sigue estando en gran medida en el nuevo LVI. Es de esperar que por parte de todos a los que corresponda hacerlo, se lleve a cabo el esfuerzo por conocerlo y entenderlo, pues esto es imprescindible para potenciar su aplicación y que no volvamos a estar en situaciones de las que se quiere salir. Es verdad que la complejidad del derecho canónico penal, lo intrincado que es, su infinidad de matices y salvedades y las múltiples conexiones de sus disposiciones entre sí y con otras ramas del derecho, puede llegar a ser agotadora; pero también esconde riquezas interesantes, y refleja planteamientos y enfoques de las cosas (a veces, es verdad, con menos posibilidades de verificarse en la vida real) que son muy expresivos del ser cristiano.

\section{REFERENCIAS}

Alwan, Hanna. "Acción criminal". En Diccionario General de Derecho Canónico, coordinada y dirigida por Javier Otaduy, Antonio Viana y Joaquín Sedano. Cizur Menor. Vol. 1, 112-115. Navarra: Universidad de Navarra-Thomson Reuters Aranzadi, 2012.

Arrieta, José Ignacio. "El proyecto de revisión de Libro VI de Código de Derecho Canónico". Anuario de Derecho Canónico 2 (2013): 211-231.

Astigueta, Damián. "La persona e i suoi diritti nelle norme sugli abusi sessuali". Periodica 93 (2004): 623-691.

Aznar Gil, Federico R. Delitos de los clérigos contra el sexto mandamiento. Salamanca: UPSA, 2005.

Aznar, Federico. "Los «delicta graviora» reservados a la Congregación para la Doctrina de la Fe. Texto modificado (2010)". Revista Española 
de Derecho Canónico 68 (2011): 283-313. https://doi.org/10.36576/ summa.30703

Boni, Geraldina. La recente attività normativa eclesiale. Finis terra per lo ius canonicum? Mucchi Editore, 2021.

Borras, Alphonse. Les sanctions dasn l'Église. Paris: Éditions Tardy, 1990.

Cabrera Martín, Myriam. La victimización sexual de menores en el Código Penal español y en la política criminal internacional. Madrid: Dykinson, 2019. https://doi.org/10.2307/j.ctvk3gnr5

Calabrese, Antonio. Diritto Penale Canonico. 2. ${ }^{\mathrm{a}}$ ed. Città del Vaticano: Librería Editrice Vaticana, 1996.

Calabrese, Antonio. "Comentario al c. 1720". En Comentario exegético al Código de Derecho Canónico, dirigida y coordinada por Ángel Marzoa, Jorge Miras y Rafael Rodríguez-Ocaña. 3. ${ }^{a}$ ed. Vol. 4/2, 2075-2081. Barañáin-Navarra: EUNSA, 2002.

Campos, Francisco. "Derechos fundamentales del investigado y aplicación de medidas cautelares. Un estudio a partir del art. 19 de las «normas sobre delitos más graves»". Revista Española de Derecho Canónico 74 (2017): 369-423. https://doi.org/10.36576/summa.48596

Cito, Davide. "La prescrizione in materia penale". En Processo penale e tutela dei diritti nell'ordinamento canonico, editada por Davide Cito, 209-233. Milano: Giuffrè Editore, 2005.

Cortés, Myriam. "La investigación previa en el proceso administrativo penal”. Revista Española de Derecho Canónico 70 (2013): 513-545. https://doi.org/10.36576/summa.32505

Dhas, V. G. "Il delitto di pornografia minorile da parte di un chierico". Apollinaris 87 (2014): 149-170.

Delgado del Río, Gregorio. La investigación previa. La respuesta de la Iglesia al delito de abuso sexual. Navarra: Editorial Aranzadi, 2014.

Felipe Freije, Rafael. "Respuesta eclesial y canónica a los abusos sexuales de menores bajo el impulso de J. Ratzinger, prefecto y papa". Tesis doctoral en Derecho Canónico, Universidad Pontificia Comillas, 2019.

Ferrer Usó, Valeska. “"Misericordia quiero y no sacrificios» (Os 6,6). Posibles vías de reconciliación en el supuesto del abuso sexual a menores". Estudios Eclesiásticos 95, n. ${ }^{\circ} 375$ (2020): 913-953. https://doi. org/10.14422/ee.v95.i375.y2020.006

García Faílde, Juan José. Tratado de Derecho Procesal Canónico. Salamanca: UPSA, 2005. 
Gidi, Marcelo. "Lo statuto penale del minore nel can. c. 1395 § 2: analisi critica alla luce dei presupposti dottrinali della teoria penale del bene giuridico". Periodica 108 (2019): 1-34.

John Jay College of Criminal Justice. The Nature and Scope of the Problem of Sexual Abuse of Minors by Catholic Priests and Deacons in the United States: Washington DC. USCCB, 2004.

Martens, Kurt. "Les délits les plus graves réservés à la Congrégation pour la Doctrine de la Foi”. Revue de Droit Canonique 56 (2006): 201-221.

Marzoa, Ángel. "Comentario al c. 1324". En Comentario exegético al Código de Derecho Canónico, dirigida y coordinada por Ángel Marzoa, Jorge Miras y Rafael Rodríguez-Ocaña. 3. ${ }^{\text {a }}$ ed. Vol. 4/1, 315-324. Barañáin-Navarra: EUNSA, 2002.

Marzoa, Ángel. "De poenis in singula delicta. Introducción". En Comentario exegético al Código de Derecho Canónico, dirigida y coordinada por Ángel Marzoa, Jorge Miras y Rafael Rodríguez-Ocaña. 3. ${ }^{a}$ ed. Vol. 4/1, 461-467. Barañáin-Navarra: EUNSA, 2002.

Miras, Jorge. "Precepto penal". En Diccionario General de Derecho Canónico, coordinada y dirigida por Javier Otaduy, Antonio Viana y Joaquín Sedano. Cizur Menor. Vol. 6, 358-360. Navarra: Universidad de Navarra-Thomson Reuters Aranzadi, 2012.

Mosconi, Marino. "Lindagine previa e la l'applicazione della pena in via amministrativa". En I giudizi nella Chiesa. Processi e procedure speciali, editado por Gruppo italiano docenti di Diritto Canonico, 191-228. Quaderni della Mendorla 7. Milano: Glossa, 1999.

Orts Berenguer, Enrique, y Carlos Suárez-Mira Rodríguez. Los delitos contra la libertad e indemnidad sexuales. Valencia: Tirant lo Blanch, 2001.

Paolis, Velasio de, y Davide Cito. Le sanzioni nella Chiesa. 2. ${ }^{a}$ ed. Roma: Urbaniana University Press, 2001.

Paolis, Velasio de. "Norme de gravioribus delictis riservati alla Congregazione per la Dottrina de la Fede". Periodica 91 (2002): 273-312.

Papale, Claudio. Il processo penale canonico. Commento al Codice di Diritto Canonico Libro VII, Parte IV. Città del Vaticano: Urbaniana Universtiy Press, 2007.

Pighin, Bruno F. Diritto penale canonico. Venezia: Marziamun Press, 2008.

Rella Ríos, Antonio. "El abuso sexual en la Iglesia. Conceptualización y tratamiento canónico". Anuario de Derecho Canónico 10 (2021):15-91

Renken, John A. The Penal Law of the Roman Catholic Church. Ottawa: Saint Paul University Press, 2015. 
Ríos, Julián. La prisión perpetua en España. San Sebastián: Gakoa Liburuak, 2013.

Sánchez-Girón, José Luis. "Algunos interrogantes en la disciplina codicial sobre la prescripción de la acción criminal”. En «Iustitia et Iudicium». Studi di Diritto Matrimoniale e Processuale Canonico in onore di Antoni Stankiewicz, editada por Janusz Kowal y Joaquín Llobell, vol. 4, 2167 2186. Città del Vaticano: Libreria Editrice Vaticana, 2010.

Sánchez-Girón, José Luis. "Penas medicinales y expiatorias". En El Código de Derecho Canónico de 1983. Balance y perspectivas a los 30 años de su promulgación, editado por José Luis Sánchez-Girón y Carmen Peña, 269-295. Madrid: Publicaciones de la Universidad Pontificia Comillas, 2014.

Sánchez-Girón, José Luis, “El m. p. «Como una madre amorosa» a la luz de la normativa codicial”. Estudios Eclesiásticos 91, n. ${ }^{\circ} 359$ (2016): 843-860. https://revistas.comillas.edu/index.php/estudioseclesiasticos/ article/view/7720

Sánchez-Girón, José Luis. "El «motu proprio» «Vos estis lux mundi»: contenidos y relación con otras normas del derecho canónico vigente". Estudios Eclesiásticos 94, n. ${ }^{\circ} 371$ (2019): 655-703. https://doi. org/10.14422/ee.v94.i371.y2019.001

Sánchez-Girón, José Luis. "Nuevos desarrollos en el proyecto de reforma del Derecho Canónico Penal”. Revista Española de Derecho Canónico 76 (2019): 271-314.

Sánchez-Girón, José Luis. “Análisis de la situación canónica que comportan las penas latae sententiae no declaradas". Estudios Eclesiásticos 95, n. ${ }^{\circ} 375$ (2020): 881-911. https://doi.org/10.14422/ee.v95.i375.y2020.005

Steinfels, Peter. A people adrift. New York-London: Simon and Schuster, 2003.

Uriarte Valiente, Luis María. Delitos relativos a la pornografía infantil y corrupción de menores. Madrid: Estudios jurídicos, 2006.

Urru, Angelo Giuseppe. Punire per salvare. Il sistema penale nella Chiesa. Roma: Edizioni Vivere in, 2001.

Valsecchi, Alfonso. "Pena e perdono. Provocazioni interdisciplinari per la Teologia”. La Scuola Cattolica 135 (2007).

Woestman, William H. Ecclesiastical Sanctions and the Penal Process. 2. ed. Ottawa: Saint Paul University, 2003. 